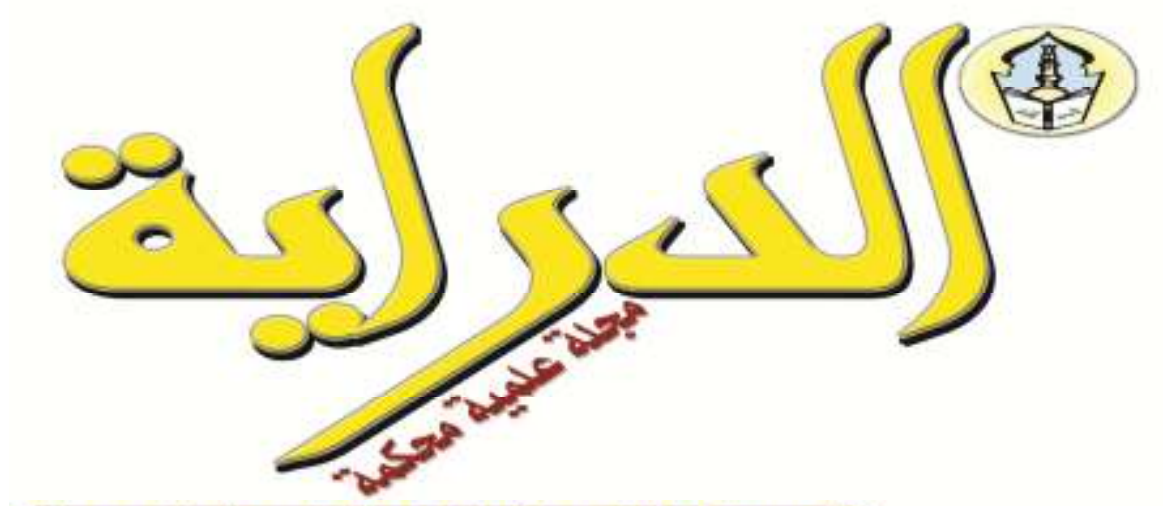

تصدرها كلية الدراسات الإسلامية والعربية بنين بلدسوق

ملى حجية الاستماذة بـالخبير في البيع بشرط

الملاق والتجربة في الفقه الإسلامي

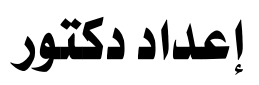

عادل عبد الله جمفر الفخري

الأستاذ الشارك بقسم الشريعة بكلية الشريعة والأنظمة

جامعة الطائف 


\begin{tabular}{|c|c|}
\hline العلدد الخامس عشر 10+rم & مجلــة اللدرايـــة \\
\hline
\end{tabular}




\section{د/عادل عبل الله جعفر الفخري}

\section{ملى حجية الاستعانة بالخبير في البييع}

\section{المقدهية:}

$$
\text { بسم الله الرحمن الرحيم }
$$

و الحمد اله رب العالمين - و الصلاة و السلام على المبعوث رحمة

للعالمين، سيدنا محمد و على إله وصحبه و التابعين.

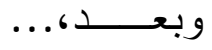

سأتتاول في هذه المقدمة بيان أهمية الموضوع، و الدر اسات السابقة فيه وسبب اختياره وخطة البحث، وذلك على النهو التالي:

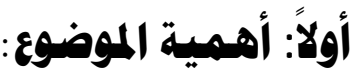

تمنت الاستعانة بالخبير أهمية كبرى في التعرف على كنهة الثيء خاصة إذا كان محل التعاقد من ذوي التعقيد الصناعي و الهندسي بحيث لا يكون للثخص العادي قدرة على إدر الك حقيقة المبيع بنفسـ، فقد شهد

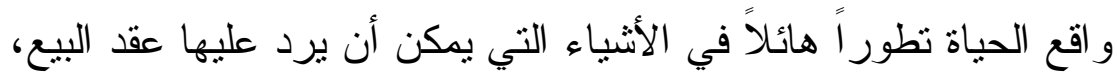
فلم يعد الأمر قاصراً على بيع الثوب و الحذاء و الدابة و الناقة و الطعام و الثراب، ولكنه تعدى ذلك إلى كثير من الأجهزة و الأدوات التي تدخل العلم و التكنولوجيا و الهندسة في صناعتها بما لا يجعل للشخص العادي المقدرة على إدر الك مدى صلاحيتها أو معرفة حالتها التي تمكن من أن وهان يكون رضاه الصحيح بها(')، بما يقتضي منه الاستعانة بشخص ذو دو

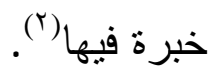

(1) في نفس المعنى - د. عبد اله مبروك النجار - مبادئ عقد البيع - ص17 ـ 1 - ط دار النهضة

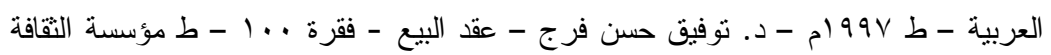

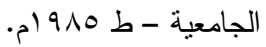

(Y) د. حسني محمد جاد الرب - تجربة المبيع و أثر ها على التزامات الطرفين في

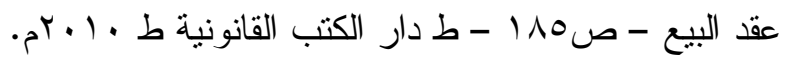




\begin{tabular}{|c|c|c|}
\hline العدد الخامس عشر 10+rم & $r \cdot r$ & مجلـة الدرايـــة \\
\hline
\end{tabular}

و إذا كانت الاستعانة بالخبير لازمة في كل العقود الفورية منها و المعلقة على شرط، إلا أن أكثر مجالات استعمالها في العقود المعلقة على شرط إذ إن تكوين رأي الخبير في معرفة حال المبيع غالباً ما إلا يستاعي وقتاً قد يكون قصيراً إلى حد ما أو طويلاً يزيد عن اليومين أو أو الثناثة كالبيع بشرط التجربة و البيوع المعلقة على شرط الرؤية للتحقق من معرفة أحو ال المبيع.

\section{ثانياً: الدراسات السابقة:}

بعد البحث و التتبع في كتب فقهاء المذاهب الإسلامية وفي الأبحاث و الرسائل العلمية فيما تيسر لي الاطلاع عليه لم أجد باحثًا أو فقيهاً أفرد الاستعانة بالخبير ببحث مستقل، ولكن ما كتب ما هو إلا بالا كلمات متتاثزة في أبواب متفرقة تتاولت الاستعانة بالخبير أو إبداء النصيحة منل كتاب نصيحة الملوك للإمام الماوردي - ط مكتبة الثروق - ط V V. r - وكتاب الالتز ام بالنصيحة في مجال النشييد

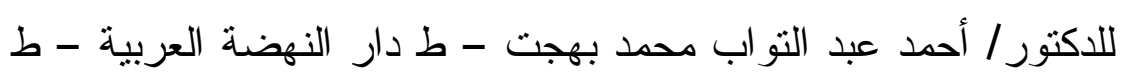
99V ومبدأ الشورى في الإسلام.

\section{ثالثً: سبب اختيار الموضوع:}

يرجع سبب اختياري لهذا الموضوع هو كما سبق له من أهمية في مجال المعاملات حيث لا يكاد يبرم عقد بدون اشتر اط عرض المبيع

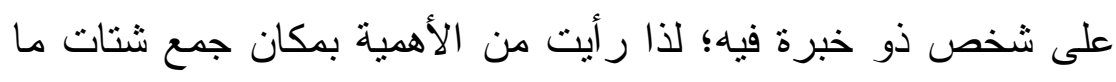
تتاثز عنه في الكتب السابقة أو الموضوعات أو من بين السطور في 


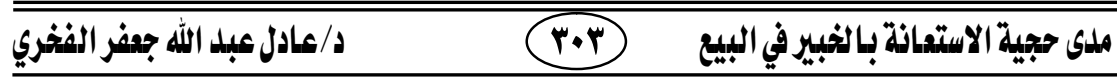

بحث مستقل تتاولت فيه حكم تلك الاستعانة وطبيعة يد الخبير حالة قبضه للمبيع خلال المدة المتفق عليها وبيان مدى حجية تللك الاستعانة.

\section{رابهاً: خطة البحث:}

تتاولت بحث هذا الموضوع من خلال هقدمة ونصلين:

أما المقدمة فتتنمل على أهمية الموضوع و الدراسات السابقة فيه وسببـ اختياره وخطة البحث:

الفصل الأول: في تعريف الخبير وضوابط الشروط المقترنة بالعقد و الصفات الو اجب تو افرها في الخبير، ويشتـمل على مبشثين: المبحث الأول: في تعريف الخبير ومدى الحاجة إليه، وضوابط الثروط المقترنة بالعقد، ويشتهمل على هطلبين: المطلب الأول: في تعريف الخبير و أهميته وتعريف البيع بشرط

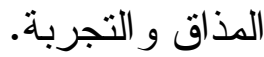

الاملب الثانب: ضو ابط الثروط المقترنة بالعقد. المبحث الثاني: الصفات الواجب توافرها في الخبير وطبيعة النصيحة التي يبديها. الاملب الأول: الصفات الو اجب تو افرها في الخبير . الاملب الثانب: طبيعة النصيحة وبيان أثزها على علاقة الخبير بالمشتري. 


\begin{tabular}{|c|c|c|}
\hline العدد الخامس عشر 10بم م & r.Q & مجلـة الدرايــــة \\
\hline
\end{tabular}

الفصل الثاني: حجية الاستعانة بالخبير في الفقه الإسلامي، وطبيعة يد الخبير على الثيء المبيع، ويشتـمل على هبمثين: المبحث الأول: في حجية الاستعانة بالخبير في الفقه الإسلامي ويشتسهل على هطابسين:

الاطلاب الأول: حجية الاستعانة بالخبير في البيع بشرط التجربة. الاطلاب الثاني: حجية الاستعانة بالخبير في البيع بشرط المذاق. المبحث الثاني: طبيعة يد الخبير على الثيء المبيع، ويشتـمل على هطابين:

المطلب الأول: تعريف الوديعة، وبيان أسباب مسئولية الخبير. الاملب الثاني: مسقطات ضمان الخبير (موانع المسئولية). الخاتمة: ويشتمل على نتائج البحث، وأهم التوصيات وفهرس المر اجع وفهرس الموضو عات. 


ملى جوية الاستعانة بالثبير في البييع

\section{الفصـل الأول}

تعريف الحبير وضوابط الشروط المترنة بالققد

والصفات الواجب توافرها في الحبير 


\begin{tabular}{|c|c|c|}
\hline العدد الخامس عشر 10+rم & $r+7$ & مجلــة الدرادـــة \\
\hline
\end{tabular}

\title{
البمشث الأول
}

\section{تعريف الخبيز وأهميية الاستعانة به وضهابط الشروط الإقترنة بعقد البيع بشرط المذاق والتجربة}

\author{
الإطبا الأول \\ تعريف الخبير وأهسمية الاستعانة به وتمريف البيع \\ بشرط المذاق والتجربة وها يندرجان تهته هن أنواع الخيارات \\ أولاً: تهريف الفبيز في الفقه الإسلاهي: \\ أولاً: تعريف الخبير لغة:
}

يطلق الخبير ويراد به: من علم بالثيء جاء في معاجم اللغة .. خبر الرجل خبوراً أي صار خبيراً وهو ذو الخبرة وهو الذي يخبر الثيء بعلمه(')، وهو اسم من أسماء الله الحسنى أي العالم بما كان وما

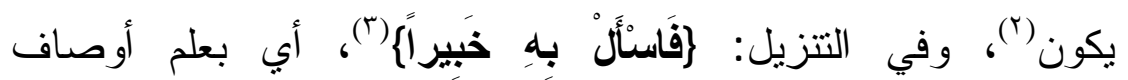

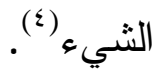

ثانياً: تعريف الخبير في اصطلاح الفقهاء:

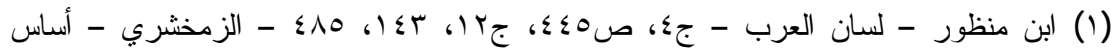

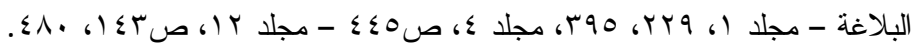

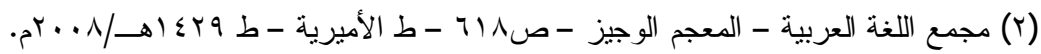

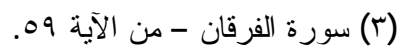

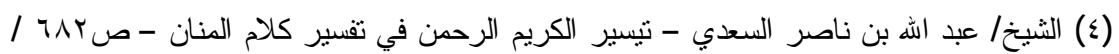

$$
\begin{aligned}
& \text { ط دار السلام. }
\end{aligned}
$$




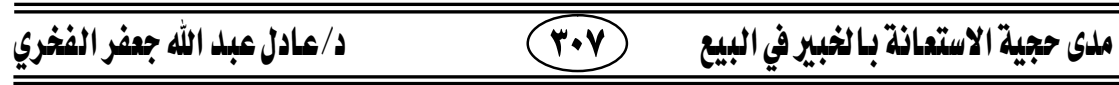

لم يرد في كتب فقهاء المذاهب الإسلامية تعريف محدد للخبير كماء لكن قد جاء في كتب بعض المفسرين ما يفبد أن معنى الخبير هو العالم

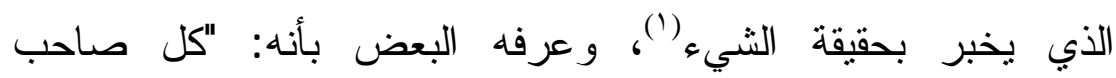

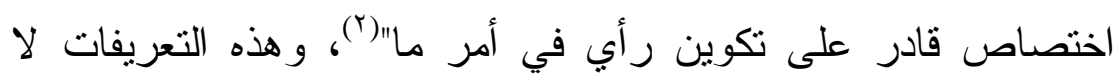
تخرج عن معنى الخبير لغة.

و الخبير قد يكون شخصاً وهو الذي ينصرف إليه اللفظ عند الإطلاق، كما قد يكون أداة كما هو الثأن في وسائل التقنية الحديثة ففي مجال المعامالات المالية أصبح التعامل بالسلم و التعاقد به في الأواني (r)،

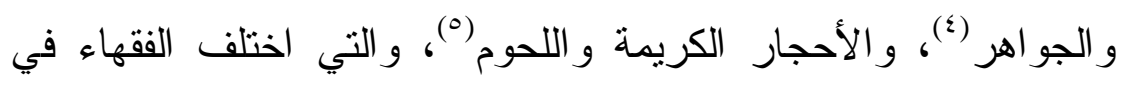
إمكان ضبطها بالوصف من الأمور السهلة عند التجار في هذا الزمن،

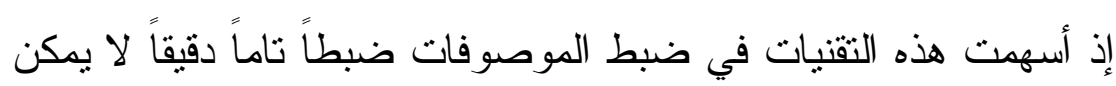
أن يختلف إلا نادراً (T).

(1) هاني الحاج - مختصر تفسير ابن كثثر - جr، صع VV - ط المكتب التوفيقية - د. محمد سيد

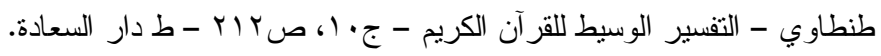

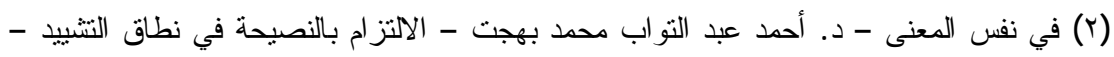

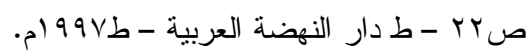

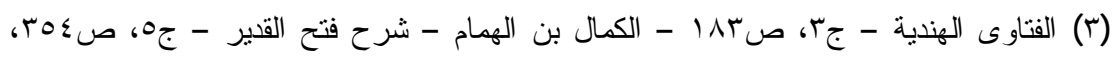

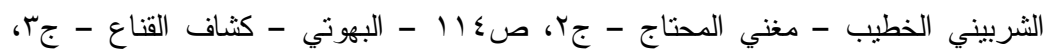

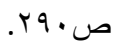

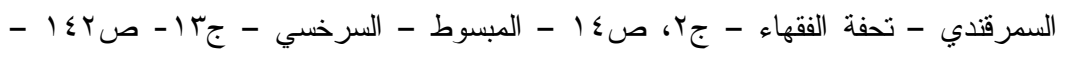

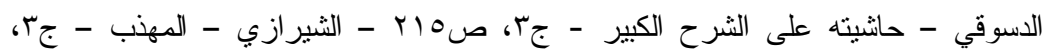

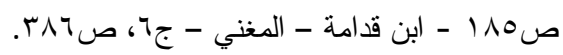

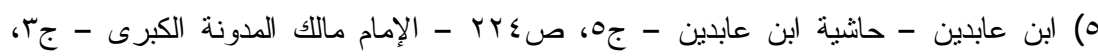

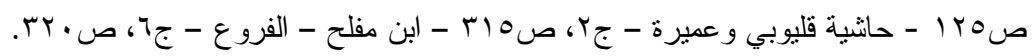

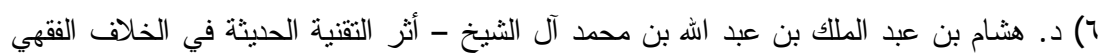

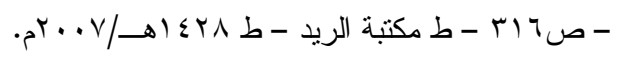




\begin{tabular}{|c|c|c|}
\hline العدد الخامس عشر 10+rم & $r+1$ & مجلــة الدرادـــة \\
\hline
\end{tabular}

\section{ثانيًا: أهمية الاستعانة بالخبير:}

الخبير هو كل صاحب اختصاص في مجالات الحياة المتشعبة

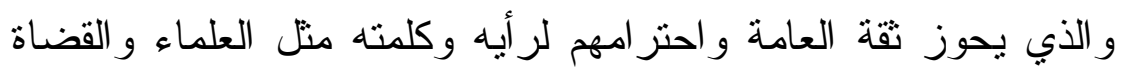

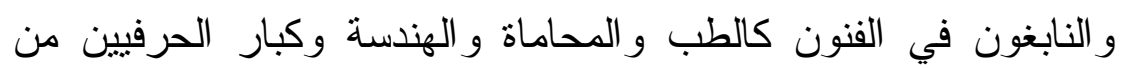

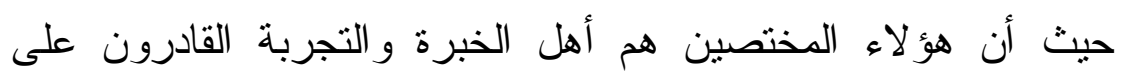

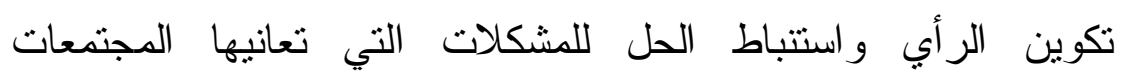

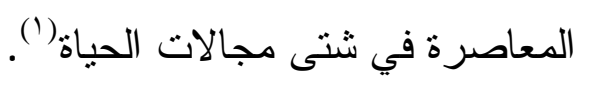

لذا جاءت الدعوة إلى اللجوء إليهم عند الجهل بالثيء في قوله

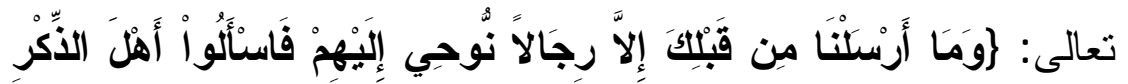

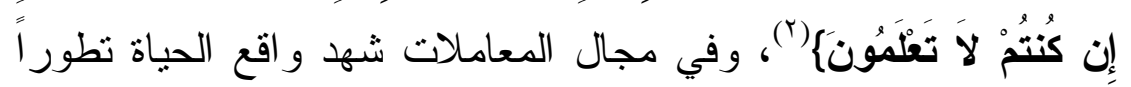

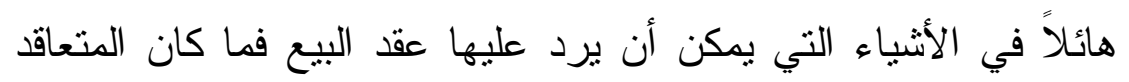

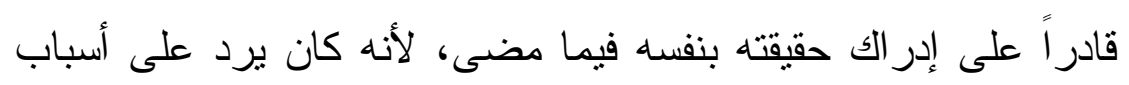

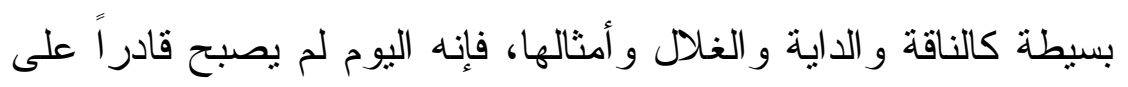

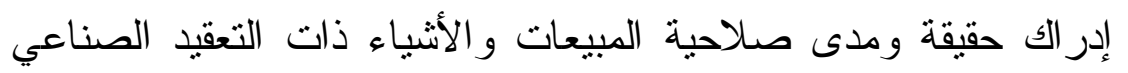
نتيجة التقدم العلمي و التكنولوجيا و الهندسة، مما يقتضي منه الاستعانة بشخص ذو خبرة فيها").

(1) ابن تيمية - الحسبة في الإسلام - صبr - في نس المعنى - النووي - شرح الأربعين

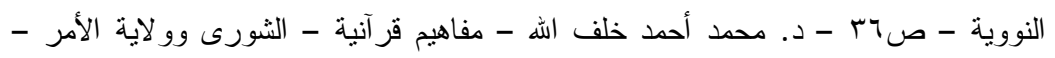

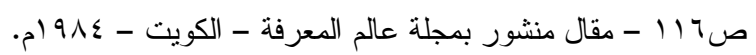

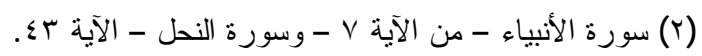

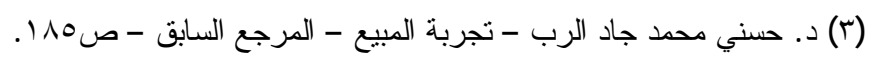




\section{ثالثاً: تعريف البيع بشرط المذاق والتجربة، ومها يندرجان تهته هن أنواع الخيارات:}

\section{أولاً: تعريف البيع بشرط المذاق، وها يندرج تمته هن أنهاع}

\section{الخيارات ومدى حاجته للاستعانة بالخبير:}

أها البيع فيطلق ويراد به لغة: مبادلة سلعة بمال(')، وفي

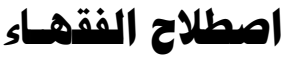

فهو: مبادلة المال بالمال بالتز اضي بطريق الاكتساب(؟)، و اثشتراط المشترى ذوق المبيع يعتبر من الأوصاف المقترنة بالتر اضي في عقد البيع والتي تعدل التزامات الطرفين فيه، كما أنه يعتبر وسيلة يتخذها المشتري للاستعلام و التحقق من مدى صلاحية الثيء المبيع لتحقيق

الأغر اض المخصصة له (").

- و وعلى ذللك فإن شرط المذاق لا يخرج عن كونه خيار محدد

بمدة معلومة، والخيار لغة: طلب خير الأمرين إما إمضاء العقد أو فسخه وهو اسم مصدر من الاختيار والانتقاء يقال: خيره بين الثيئين

$$
\text { (1) مجمع اللغة العربية - المعجم الوجيز - ط الأميرية - ط ا ل. بام. }
$$

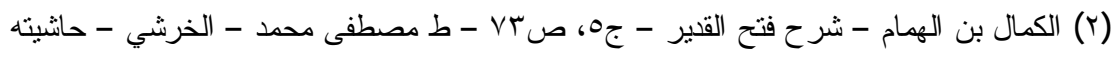

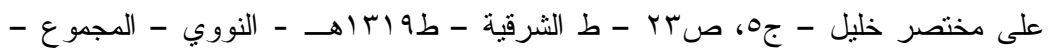

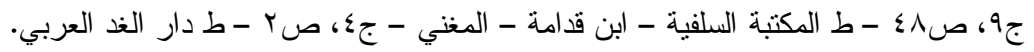
(r) د. ممدوح محمد علي مبروك - أحكام العلم بالمبيع ونطبيقاته في ضوء هُ تقدم وسائل التكنولوجيا

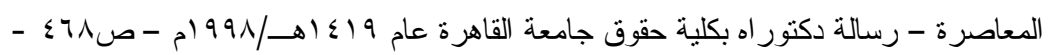

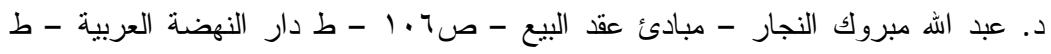

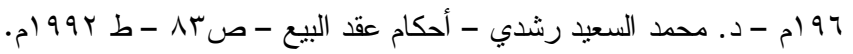




\begin{tabular}{|c|c|c|}
\hline العدد الخامس عشر 10rم & M. & مجلــة الدرايــــة \\
\hline
\end{tabular}

أي فوض إليه الخيار فاختار أحدهما(')، وفي الاصطلاح: لا يخرج عن معناه في اللغة من كونه: حق العاقد في إمضاء العقد أو فسخه(؟)، وقد قسم الفقهاء الخيارات إلى نوعين: أحدههما: خيارات إر ادية وهي التي يكون الباعث عليها هو التروي و التأمل في صلاحية الثيء

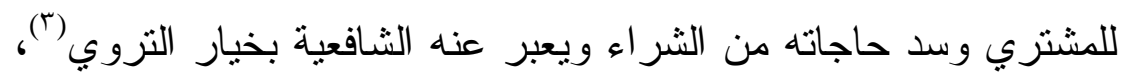
وسببـه أهمران أولهما:

1 - المشورة وتمحيص الآراء وتتقيح الأنظار للوصول إلى ما

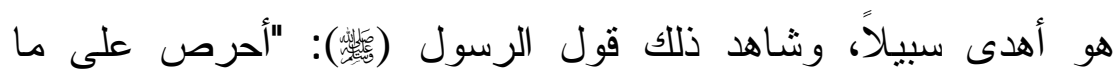

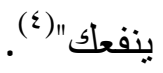

r - الاختبار وهو تبيين خبر الثيء بالذوق أو التجربة والاطلاع

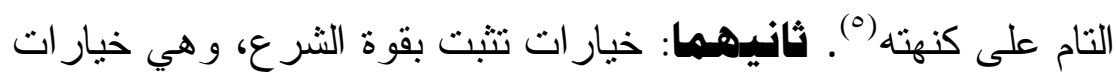
يمنح الثار ع بمقتضاها أحد العاقدين الحق في فسخ العقد أو إمضائه لإعادة التوازن العقدي بعد تعرضه للاختلال، و الغرض منها أيضاً

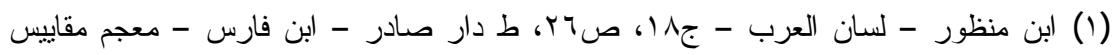

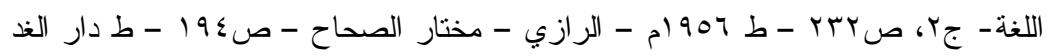

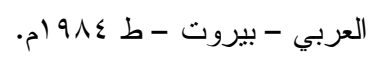

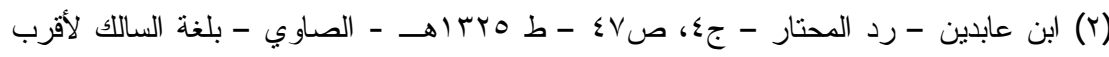

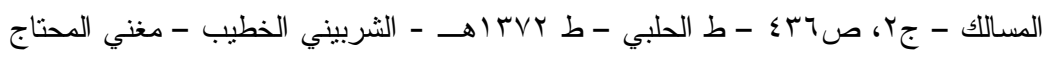

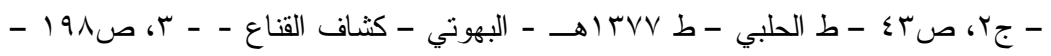
b

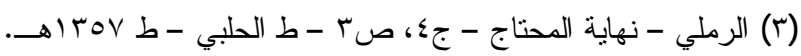

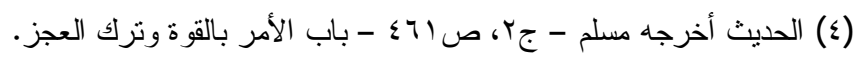

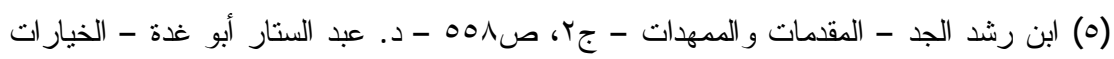

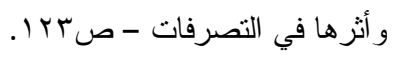




\section{د/عادل عبل الله جقفر الفخري}

ملى حجية الاستعانة بالثبير في البييع

تمحيص الإر ادنين وتتقية عنصر التراضي من الثوائب التي لحقت بـ توصلاً إلى دفع الضرر عن العاقد (').

\section{أمها عن تعريف البيع بشرط المذاق: فيطلق وير اد به التجربة} و الاختبار يقال: ذاق الثيء جربه واختبره ويقال: ذاق الطعام ذوقاً وذوقانًا ومذاقاً اي اختبر طعده، وفي اصطلاح الفقهاء: تتاول الفقه الإسلامي أحكام تذوق المبيع كوسيلة يتحقق بها العلم بحقيقة المبيع التي

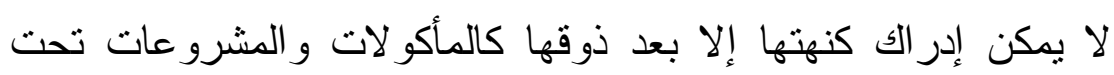
مسمى خيار الرؤية(r).

وقد توســع الفقهــاء في معنى الرؤية حتى أخذت معنى أعم من

معناها

اللفظي المتمنل في النظر و المشاهدة، فأدخلو أفيها العلم بحقيقة المبيع عن طريق الثم أو السمع أو الذوق في '. و على ذلك فإن البيع بشرط المذاق هو: عقد بمقتضاه يتذوق المشتري أو من يعينه من أهل الخبرة في المبيع قبل إمضاء العقد أو

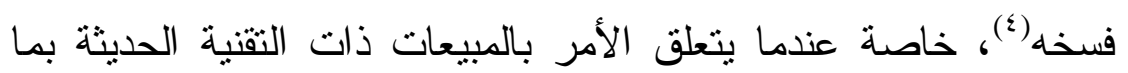
ليس في استطاعة المشتري العادي التعرف على مدى ملائمتها للغرض من شر ائها.

$$
\begin{aligned}
& \text { (1) د. عبد الستار أبو غدة - المرجع السابق - صسب إ. }
\end{aligned}
$$

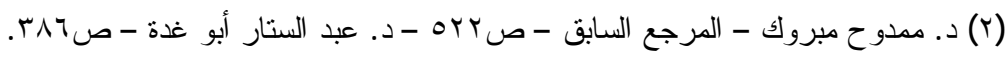

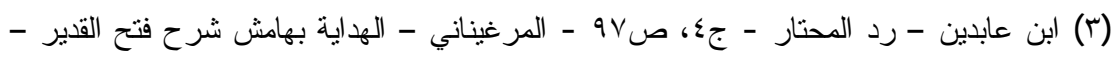

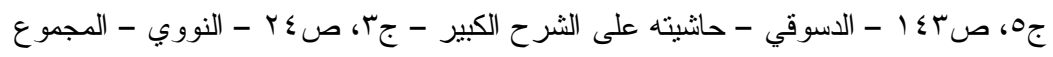

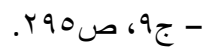

$$
\begin{aligned}
& \text { (ع) د. حسني محمد جاد الرب - تجربة المبيع - المرجع السابق - صـ؟با. }
\end{aligned}
$$




\begin{tabular}{|c|c|c|}
\hline العدد الخامس عشر 10 10م & MIY & مجلــة الدرايـــة \\
\hline
\end{tabular}

\section{ثانياً: تعريف البيع بشرط التجربة، وها يندرج تحته هن أنهاع \\ الخيارات:}

لم يرد في كتب فقهاء المذاهب الإسلامية تعريف بالمعنى الدقيق

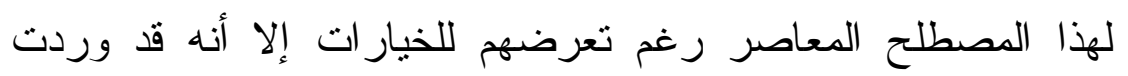
بعض التعريفات عن الفقهاء المعاصرين منها أنه بيع يحتفظ فيه المشتري بحقه في تجربة المبيع لمعرفة مناسبته له، أو مدى صلاحيته للغرض الذي أُعد له(')، هذا ويندرج البيع بشرط التجربة تحت خيار الثرط و الذي أصله حديث حبان بن منقذ الأنصاري حيث كان بلسانه

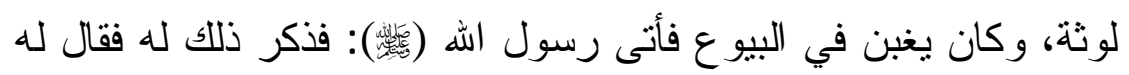

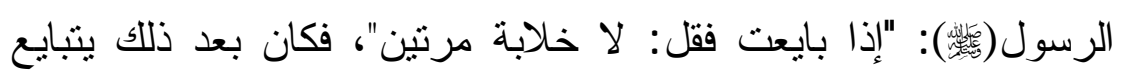
البيع في السوق، ويرجع إلى أهله، وقد غبن غبناً شديداً فيلومونه

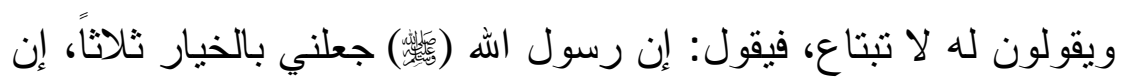

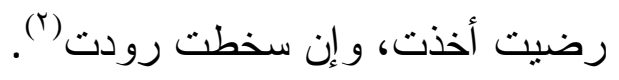

\section{وجه الاتفاق والاختلاف بين البيه بشرط المذاق والتبربة:}

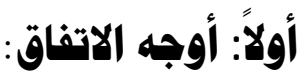

يتفق البيعان من حيث أن كلاً منهما يعد وسيلة من وسائل التأكد

من صلاحية المبيع لذوق المشتري وحاجته من الثر اء(َ).

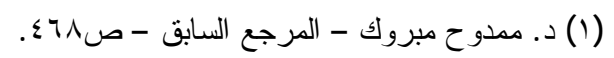

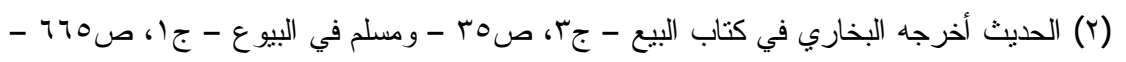

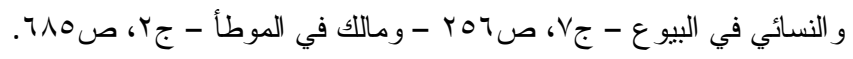

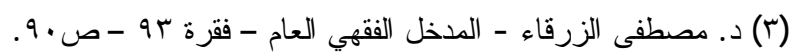




\section{ملى حجية الاستعانة بالخبير في البييع}

كما يتفقان من حيث تمتع المشتري فيهما بالحرية المطلقة في قبول المبيع أو رفضه بعد ذوقه أو تجربته(')، كما يتفقان في أن رأي الخبير فيهما لا يمثل قوة إلزامية إنما هو على سبيل الاستئناس، كما يتفقان من حيث التز ام البائع فيهما من تمكين المشتري الذي بدوره يقوم بتسليم، المبيع إلى خبير ليقوم بذوق المبيع أو تجربته خلال مدة

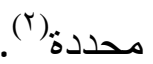

\section{ثانيًا: أوجه الاختلاف:}

يختلف البيع بشرط المذاق عن البيع بشرط التجربة من حيث أن البيع بشرط المذاق هو مجرد وعد بالتعاقد لا ينعقد البيع إلا من حين

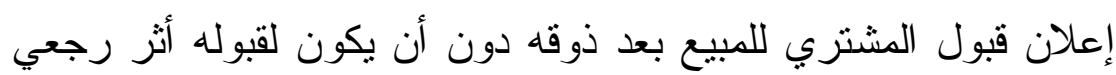

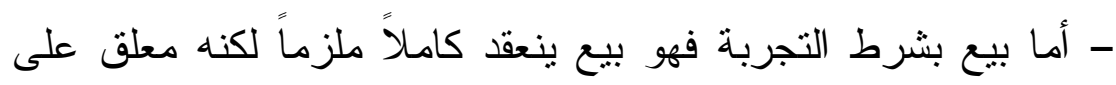
شرط، فإذا قبِل المشتري المبيع بعد تجربته ترتبت آثار العقد بأثز رجعي (r).

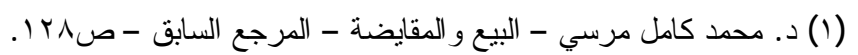

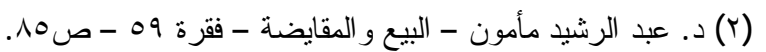

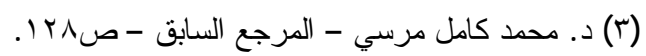




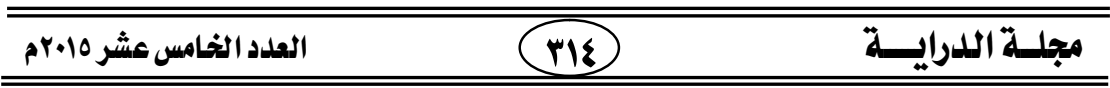 \\ الاطلب الثاني \\ ضوابط الشروط الاقتزنة بعقد البيـع بشرط المذاق والتجربة وها يندرجان تحته \\ اشتزاط الاستعانة بالنبير هن أنواع الشروط:}

الثرط الذي يقترن بالعقد إما أن يقتضيه العقد و إما أن لا يقتيه، فالثرط الذي يقتضيه العقد هو الثرط الذي يجب بنفس العقد من غير اثتر اط ومثاله شرط الملك للمشتري وشرط تسليم الثنن للبائع، فمثل هذا الثرط يفيد ما يفيده العقد المطلق (')، فوجوده كعدمه (r). و على ضوء ما تقدم يتبين لنا أن اشتر اط الاستعانة ليس من هذا النوع لإمكان تحقق العقد بدونه، كما هو الثأن في شراء الأشياء البسيطة غير معقدة الصنع (ז)، فالثرط الذي يقتضيه العقد خارج عن محل بحثنا.

\section{أها الشرط الذي لا يقتضيه الهقد فهو أمر زائد على مطلق}

العقد؛ لذا اختلف في انتزراطه الفقهاء فإذا كان الأصل في المذهب الظاهري: أن كل شرط لا يرد فيه نص فهو باطل (ع)، فإن العكس عند الحنابلة فهم يرون أن الأصل في الشروط المقترنة بالعقد هو الصحة برد بهد

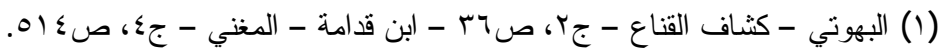

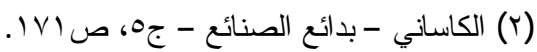

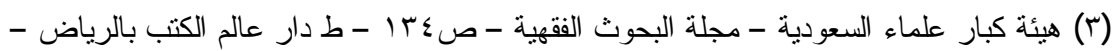




\section{ملدى ججية الاستعانة بالخبير في البييع}

و الجواز ولا يبطلون إلا شرطاً دل على تحريمه وإيطاله نص أو

قياس (1).

\section{أمها البمهور هن المنفية والمالكية والشافعية والشيعة}

الزيلدية والإهاهية والإباضية فقد قسموا الثروط المقترنة بالعقد إلى لى

$$
\text { شروط صحيحة وشروط باطلة }
$$

\section{أهـا الشروط الباطلة فمن أهثلتهها:}

$$
\text { ا - الثرط المخالف للنص (ז). }
$$

r - الثرط الذي فيه منفعة لأجنبي عن العقد (r).

r - الثرط الذي ليس فيه منفعة و لا ضرر (ع).

$$
\text { ـ ـ - شرط بيع وسلف - شرط بيعتين في بيعة(') }
$$

و الناظر إلى هذه الشروط يتبين أن اثتر اط الاستعانة بالخبير ليس منها فهو ليس من باب بيعتني في بيعة، وكذلك ليس من الثروط التي لم يرد فيها نص بتحريمها؛ لذا فإن هذه الشروط خارجية عن محل البحث

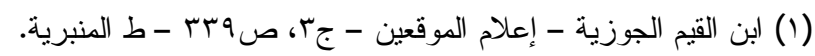

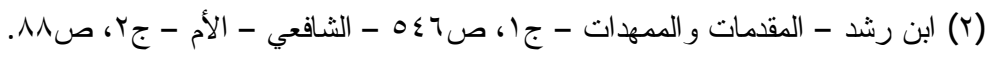

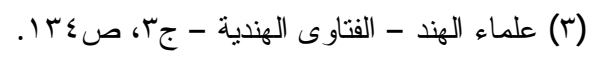

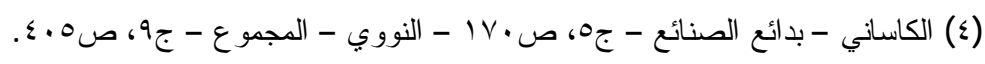

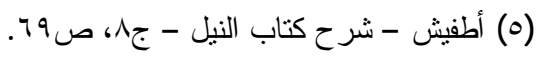

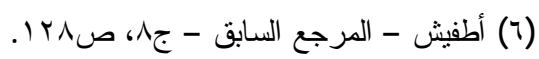

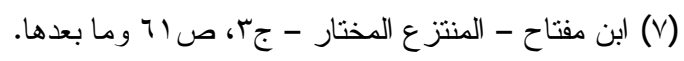




\begin{tabular}{|c|c|}
\hline العدد الخامس عشر 10بم & مجلـة اللدرايـــة \\
\hline
\end{tabular}

\section{أها الشروط الصحيحة فقد قسموها إلى أربعة شروط هي:}

ا - الثرط الملائم للعقد، وفيه مصلحة له (').

r - الثرط الذي ثبتت صحته بالنص (r)

r - الثرط الذي فيه معنى من معاني البر (").

ع - الثرط الذي فيه منفعة يسيرة للمعقود عليه(ع).

ولما كان في اثتر اط الاستعانة بالخبير منفعة للمتعاقد تتمنل في

مساعدته على التعرف على حقيقة المبيع وكذلك شرط ملائم للعقد لأن به يتم إتمام الصفقة على رضا صحيح فيكون من الثروط التي اتفق الفقهاء على صحتها.

وسوف نعرض لأنواع الثروط في كل مذهب لبيان ما تتدرج تحته الاستعانة بالخبير من أنو اع الثروط في كل مذهب على حده.

(1) السرخسي - المبسوط - جr، ص1919 - الدسوقي - حانشيته - جr، ص10 - ط مصطفى

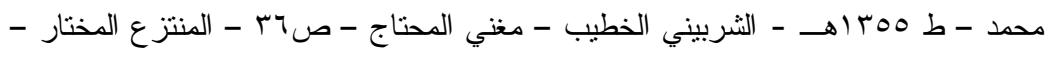

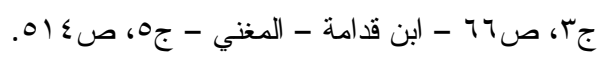

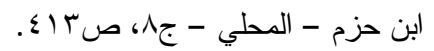

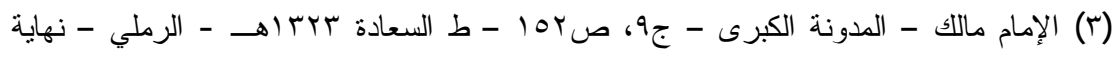

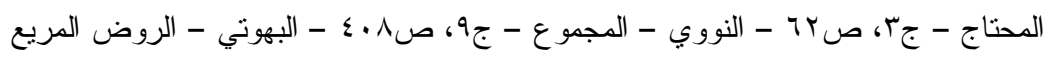

$$
\text { . } 197
$$

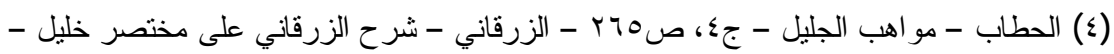

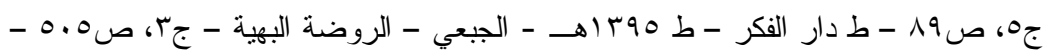

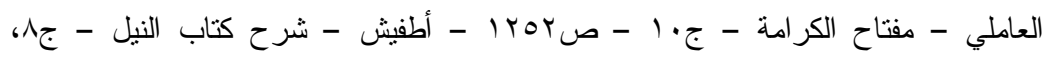




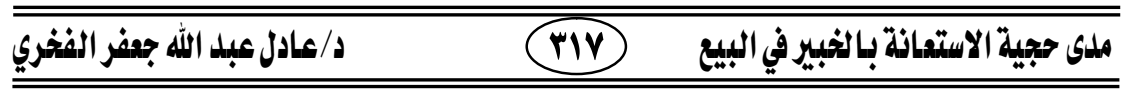

أولاً: ها تندرج تهته الاستعانة بالخبيز هن أنهاع الشروط في

حصر ابن حزم الثروط الصحيحة فيما وردت النصوص

\section{بصحتها فيسما يلي:}

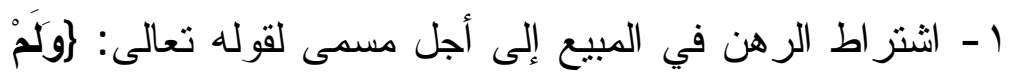

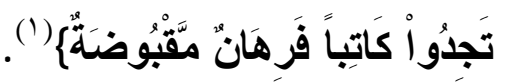

r - اثتزر اط تأجيل الثنن إن كان در اهم أو دنانير إلى أجل مسمى

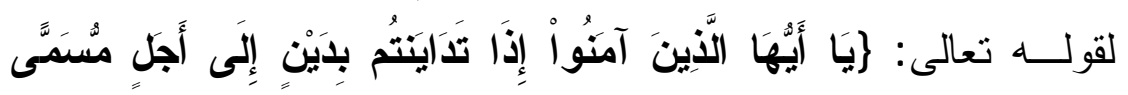
فَاكتبنُو

r - اشتر اط الخيار للتعرف على المبيع لما رواه البخاري عن

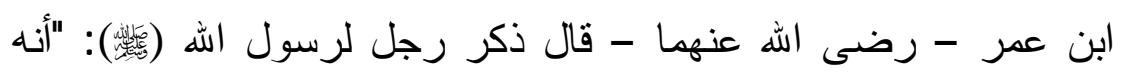

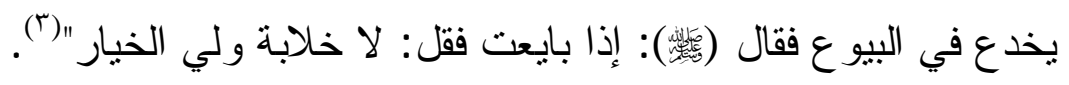
ع - انتزر اط الصفات التي يتبايع عليها المتعاقدان مثل انتتر اط

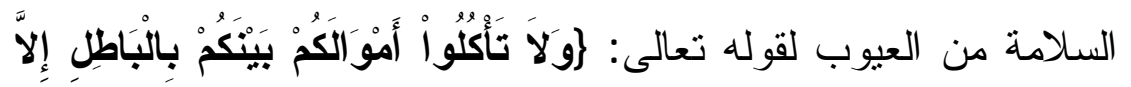

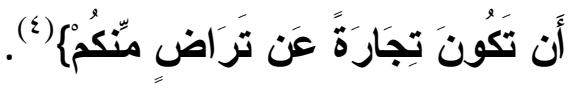

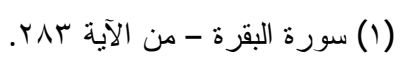

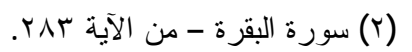

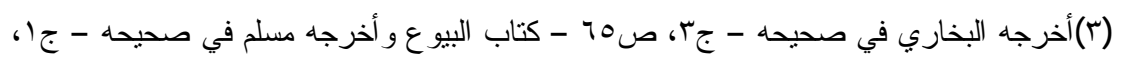

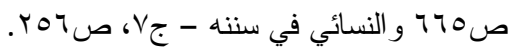

$$
\begin{aligned}
& \text { (乏) سورة النساء - من الآية وج. }
\end{aligned}
$$




\begin{tabular}{|c|c|c|}
\hline العدد الخامس عشر 10بم & MIN & مجلــة الدرايـــة \\
\hline
\end{tabular}

\section{وجسيسه الدلالـــة}

إن اله تعالى نص على التراضي في التجارة، و التراضي لا

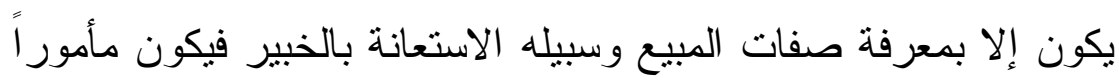

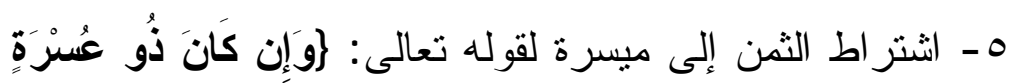

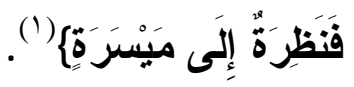

T، V- شرط مال العبد أو الأمة وشرط ثر النذل المؤبر لما

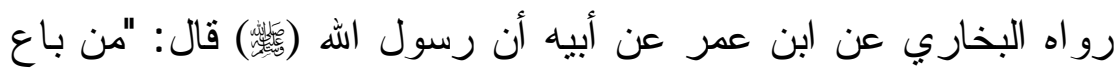

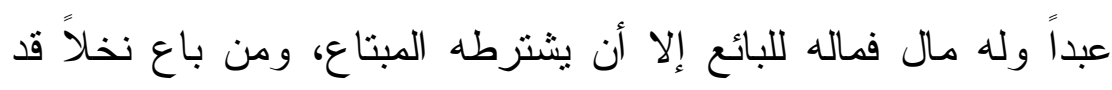

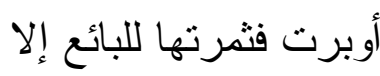

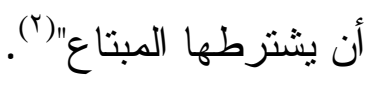

قال ابن حزم فهذه أي الثروط المذكورة، وسائرها باطل و اثنتراط الاستعانة بالخبير يندرج تحت شرط الخيار للتعرف على

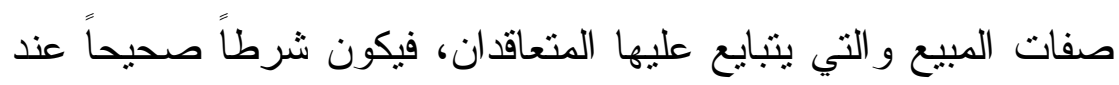

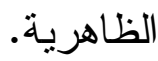

\section{ثانياً: ها تندرج تحته الاستعانة بالخبير هن أنواع الشروط

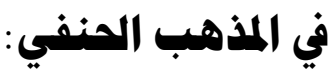

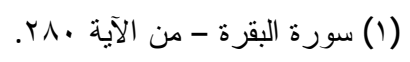

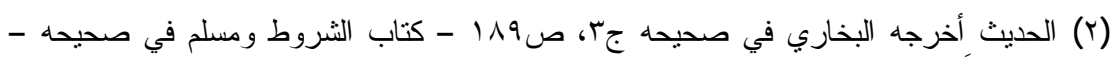

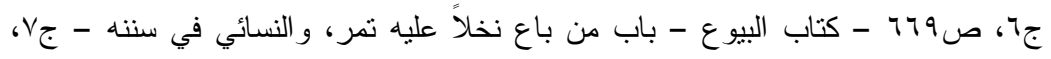

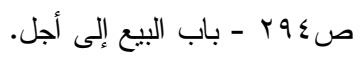




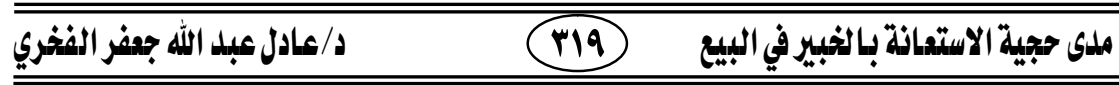

توسع فقهاء الحنفية في الثروط المقترنة بالعقود استتاداً إلى

نظرية الاستحسان في الاجتهاد الحنفي فاستثنوا من الثروط الباطلة الشرط الذي جرى به العرف منل شر اء قلنسوه على شرط أن يبطن له

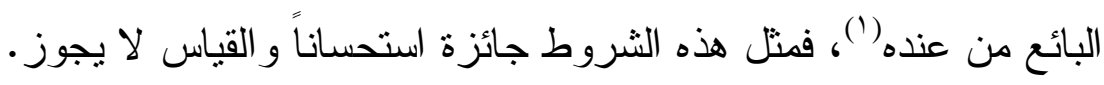

أما وجه الاستحسان أن الناس تعاملو ا بهذه الثروط كما تعاملو ا

بالاستصناع(r)

وأما وجه القياس أن هذه الثروط لا يقتضيها العقد وأن فيها

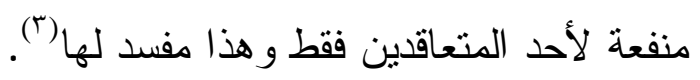

هذا وقد رد ودحض القــول بأن الأخــذ بالاستحسان يجعل

$$
\text { العرف قاضياً }
$$

على حديث نهى النبي (敬) عن بيع وشرط فقال: "أن الحديث معلول بوقوع النزاع المخرج للعقد من المقصود به وهو قطع المنازعة و العرف ينفي النز اع فكان مو اققاً للحديث وليس قاضياً عليه"(عُ ).

وبعد عرض ما جاء في المذهب الحنفي فإننا نسنطيع الجزم بأن

الاستعانة بالخبير تتدرج تحت الثرط الذي جرى به العرف و أنها جائزة

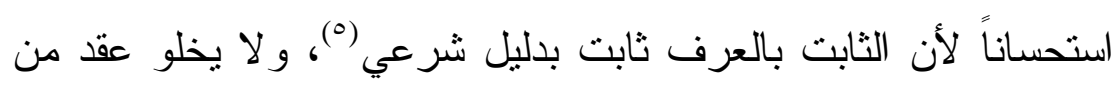

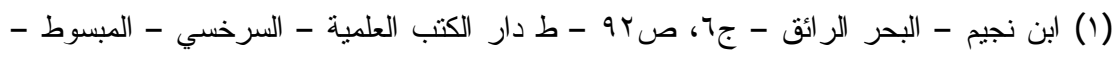

$$
\begin{aligned}
& \text { جז"ا، صع ا. }
\end{aligned}
$$

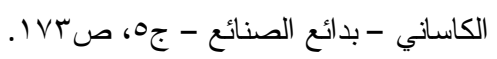

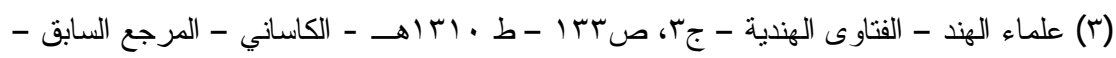

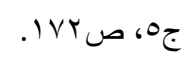

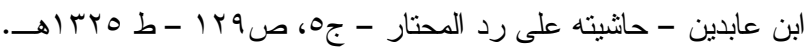

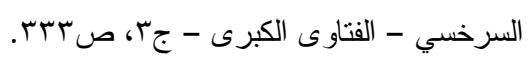




\begin{tabular}{|c|c|c|}
\hline العدد الخامس عشر 10+rم & rr. & مجلــة الدرادـــة \\
\hline
\end{tabular}

العقود المتعلقة بالأشياء معقدة الصنع من شرط الاستعانة بالخبير قبل تكوين الر أي بالقبول أو الرفض. باء معفود.

\section{ثالثًا: ها تندرج تمته الاستعانة بالخبير هن أنهاع الشروط \\ في المذهب الهنبلي:}

الأصل العام في الثروط عند الحنابلة هو الحل و الجواز وعدم

التحريم إلا بدليل وهذا عام في عقود المعاوضات أو التبرعات أو ولئ

التوثيقات (')

\section{فالشرط لا يبطل عند المنابلة إلا في هوضعين:}

أولهمها: أن يكون الشرط منافياً لمقصود العقد كثرط الضمان على الغير كأن يقول بع عبدك من فلان على أن يكون على أنى

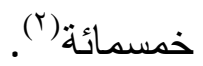

ثانيهـها: أن يكون الشرط مناقضاً للشر ع كأن يكون مخالفاً لقول

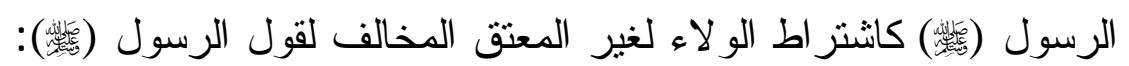

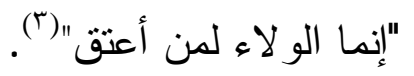

$$
\begin{aligned}
& \text { (1) ابن تيمية - الفتاوى الكبرى - جr، صسrr - ابن القيم - إعلام الموقعين - جr، صوس ا } \\
& \text { وما بعدها. }
\end{aligned}
$$

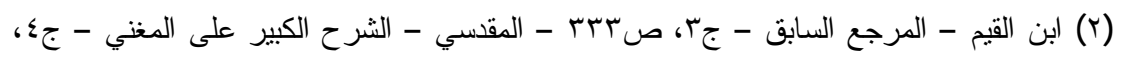

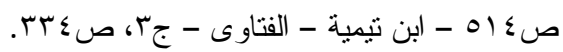

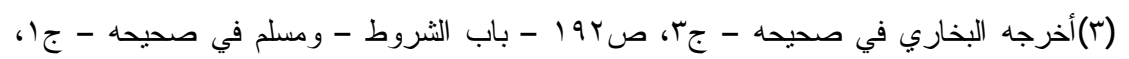

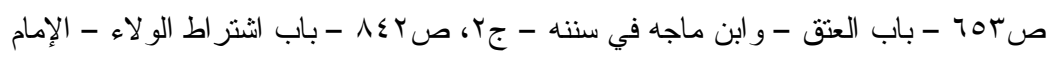

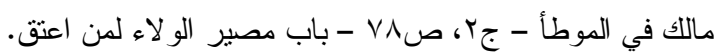




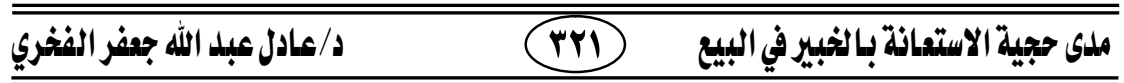

والاستعانة بالخبير لا تتافي مقصود العقد ولم تخالف قول

الرسول (赔) و لا تصادم قاعدة قطعية فتكون جائزة عند الحنابلة. 


\begin{tabular}{|c|c|c|}
\hline العدد الخامس عشر 10. مFم & MrY & مجلـة الدرايــة \\
\hline
\end{tabular}

\section{رابعًا: ها يندرج تحته الاستعانة بالخبير هن أنواع الشروط عند \\ البمهـهور:}

أجاز الجمهور من المالكية و الثافعية و الزيدية و الإمامية

و الإباضية الثرط الذي يلائم العقد وفيه مصلحته ويضمن تتفيذه كثرط

عدم التصرف في المبيع أو فسخ العقد حتى يقبض البائع الثمن (').

وشرط الاستعانة بالخبير ما قصد المتعاقد اثثتر اطه إلا للتأكد من

صلاحية المبيع للغرض المنوط به ففيه مصلحة العقد ولأنه ملزم لمن شرط له أن ينجز في تنفيذ إنمام الصفقة لتحقق الثرط فيكون جائز اً عند الجمهور و الظاهرية و الحنفية و الحنابلة.

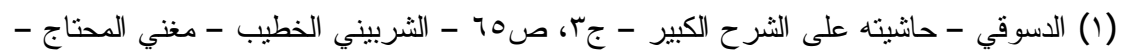

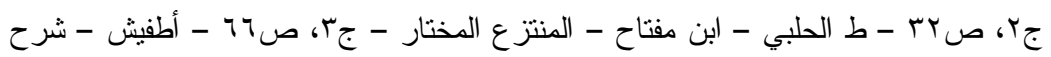


المبحث الثاني

\section{الصفات الواجب تهافرها في الخبير، وطبيعة النصيحة التي ببديها وأثرها على علاقة الخبير بالمشتزي}

\section{الإطبا الأول \\ الصفات الواجب توافرها في الخبير}

الخبير صاحب اختصاص ذو كفاءة عالية في مجاله؛ لذا يجب أن

يتحلى بصفات لا توجد عند غيره، وسوف نمرض لهذه الصفات فيسما يلبي:

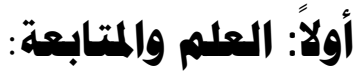

يجب على الخبير أن يكون عالماً بحقيقة ما يخبر عنه وأن يكون

من أحرص الناس على متابعة التطور ات التكنولوجية الحديثة في مجال تخصصه فلا يكتفي بما لديه من علم، بل يبحث دائماً على ما هو جديد حتى يلم بما بؤهله لممارسة مهنته بكل دقة وثقة، وحتى يبدع في مجال تخصصه فالحكمة ضالة المؤمن أينما وجدها فهو أحق بها (').

(1) د. لؤي عبد الحميد الحليمي - الأحكام الثرعية للإضر ابات في المهن الإنسانية في الفقه

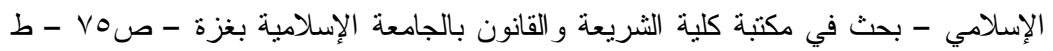




\begin{tabular}{|c|c|c|}
\hline العدد الخامس عشر 10بم & MYS & مجلــة اللدرايـــة \\
\hline
\end{tabular}

\section{ثانياً: الصدق وحسن النية:}

على الخبير أن يكون صادقاً فيما يخبر عنه فلا يكون عبداً للمال

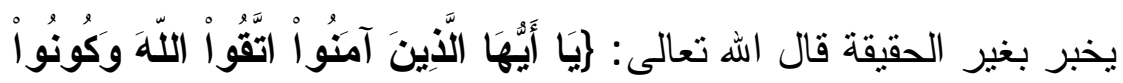

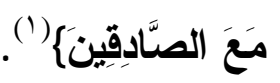

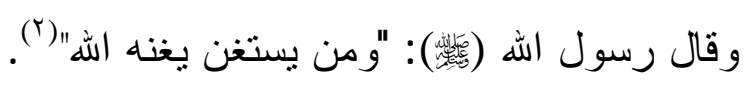

هذا ويقترب مبدأ حسن النية من فكرة العدالة وهذا المبدأ يفرض على الخبير إبداء الرأي مظهراً للعيوب التي توجد بالمبيع ليتداركها

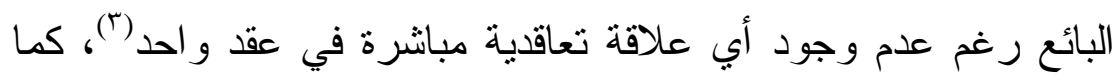

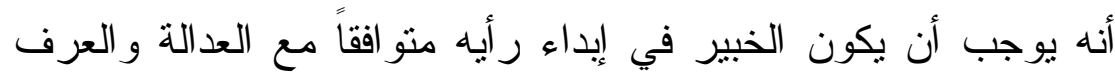
و التشريع بحسب طبيعة الالتز ام كما يوجب بيان كل ما هو من مستلزمات حقيقة الثيء المبيع (๕).

\section{ثالثًا: التواضع واستشارة الغير عند الحاجة:}

على الخبير أن يكون متو اضعاً لا يتكبر عن الاستعانة بغيره فعن

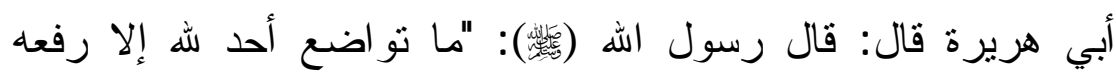
الله"(0)، فإذا تطلب التعرف على حقيقة المبيع استتسارة خبر اء آخرين

$$
\text { (1) سورة التوبة - الآية } 91 \text { (1) }
$$

(Y) الحديث أخرجه البخاري في صحيحه - جع برقم 0 (1) - كتاب الرقاق - باب الصبر على محارم اله.

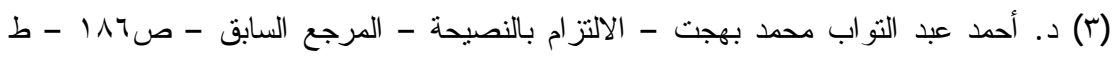
. $) 99 \mathrm{~V}$

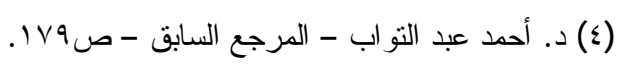

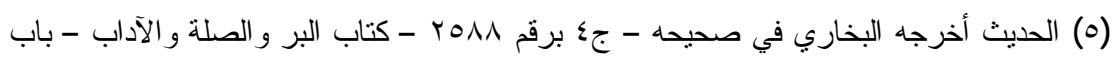
استحباب العفو و التو اضع. 


\section{ملدى حجية الاستعانة بالخبير في البييع}

حال عجزه عن إدرالك مدى صلاحية المبيع للغرض من الثراء فلا يتكبر عن استشارة من هم ذو خبرة أكثر منه (1).

\section{رابعاً: الأهانة:}

لابد أن يتصف الخبير بالأمانة وأن يكون راعياً لتلك الأمانة التي استر عاها فأداء الأمانة هي الدين كله، فلا دين لمن لا أمانة له له فال الله

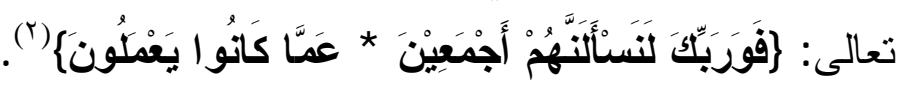

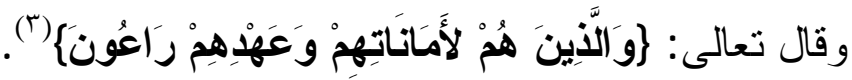

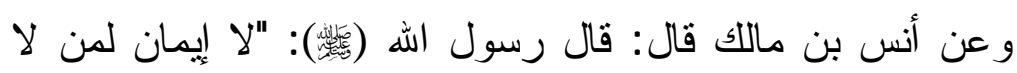
أمانة له"(£)

ومن الأمانة أن يقول الخبير فيما لا يعلم عن حقيقة الثيء لا أعلم و إذا علم عليه أن يخبر بحقيقة الثيء كاملة من غير نقص أو أو تحريف (c)

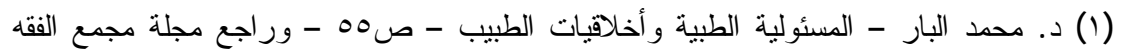

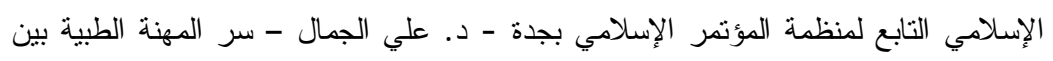

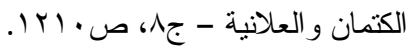

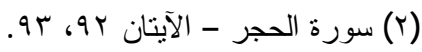

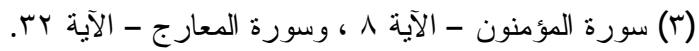

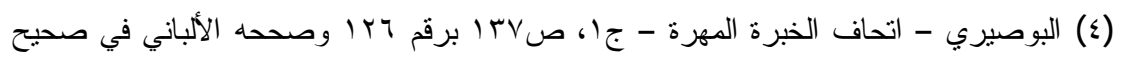

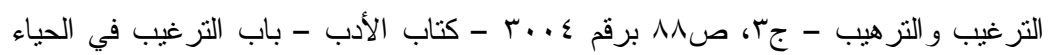

$$
\text { وما جاء فيه. }
$$$$
\text { (0) د. لؤي الحليمي - المرجع السابق - صبهـ. }
$$ 


\begin{tabular}{|c|c|c|}
\hline العدد الخامس عشر 10بrم & MYY & مجلـة الدرايـــة \\
\hline
\end{tabular}

\section{المطالب الثاني}

طبيعة النصيحة التي يبديرها الخبير ونطاق تطبيقات الالتزام بالنصيحة في عقد البيع وأثرها على علاقة الخبير بالمشتري

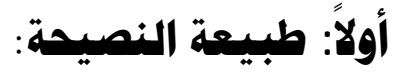

استجابة للتدرج العلمي سوف نعرض أولاً لبيان معنى النصيحة

بما يمكن لمعرفة طبيعتها، وذلك على النحو التالي: أولاً: تعريف النصيحة:

\section{ا - تعريف النصيحة لغةة:}

النصيحة: اسم الفعل في مصدره نصحه و (نصح) يقال نصح له

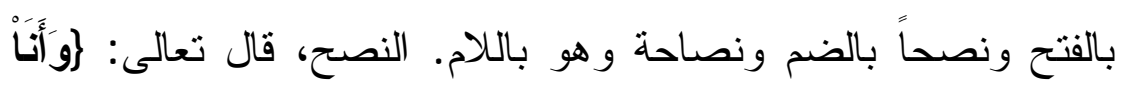

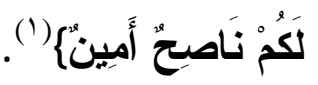

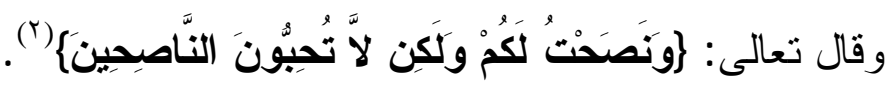

وكلها تعني إبداء الرأي و الاختيار والإعلام عن طيب خاطر

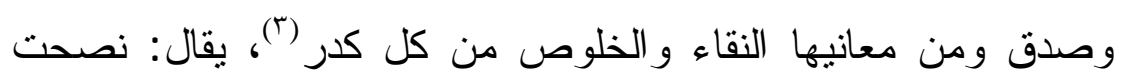

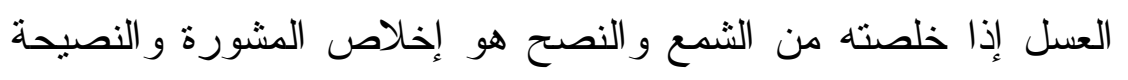

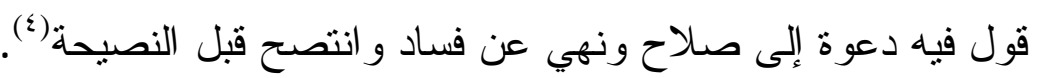

$$
\begin{aligned}
& \text { (1) سورة الأعراف - من الآية هی؟. }
\end{aligned}
$$

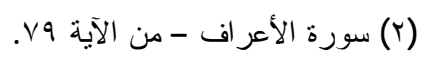

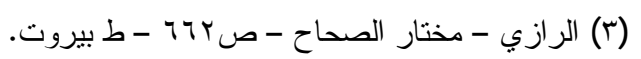

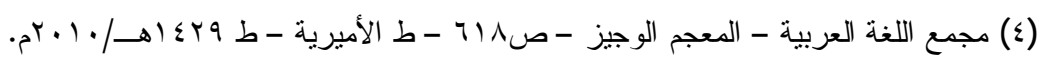




\section{r- تعريف النصيحة في اصطلاح الفقهاء:}

عرف بعض فقهاء الثريعة الإسلامية القدامى النصيحة بأنها

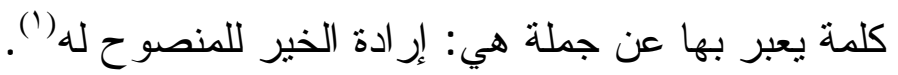

وفي المعاملات هي الإخبار و الإفصاح عن عيوب موضوع العقد

وعدم السكوت عنه أو كتمانه(r)، وعرفها بعض والإهـ المعاصرين بأنها: الر أي الذي يبدي إلى شخص ما بشأن ما يجب أن يفعل، وهذا لر أي إما بالقيام بعمل أو بالامتتاع عنه لمساعدة آخر بتوجيهه في شئونه،

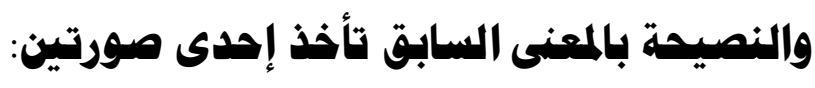

أولهمها: المبادأة بإعطاء الرأي أو الإرشادات لآخر بشأن مسلكه

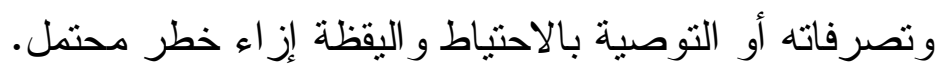

ثانيههما: بطلب الر أي و المشورة إلى صديق أو شخص محل ثقة الطالب - الدائن بالنصيحة - بقصد الأخذ بر أيه و إتباعه(").

\section{r- العلاقة بين المعنى اللغوي والاصطلاحي:}

مما سبق يتبين أن المعنى الاصطلاحي للنصيحة ير ادف معناها في اللغة و أنهما يتفقان من حيث أن النصيحة لا تخرج عن كونها إبداء الرأي والإخبار والإعلام عن طيب خاطر وصدق وبذل الوسع في إصلاح حال الغير و استقامة أمره(؛).

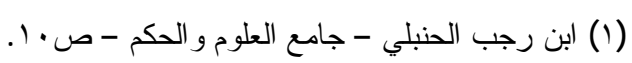

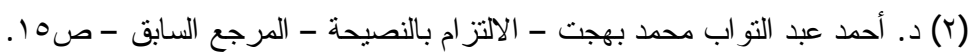

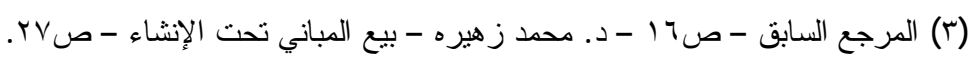

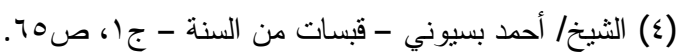




\begin{tabular}{|c|c|c|}
\hline العدد الخامس عشر 10 10م & MrA & مجلـة اللدرايـــة \\
\hline
\end{tabular}

\section{ثانيًا: طبيدة النصيحة التي يبديهها الخبهير:}

تمثل الاستعانة بالخبير في طبيعتها عقد، هذا العقد يترتب التزاماً بإبداء الرأي في الثيء محل الاستعانة للتأكد من مدى صلاحيته للغرض من الثراء؛ لذا فإن الأمر بتطلب تعريف الالتزاء وبيان طبيعته، وذلك فيما يلي:

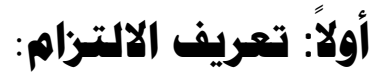

\section{ا - تعريف الالتتزام لغنة:}

يطلق الالنز ام في معاجم اللغة وير اد به الثبوت و الدوام و الوجوب

شغل الذمة بشيء يقال: التزم الشيء أي أوجبه على نفسه، ولزمه

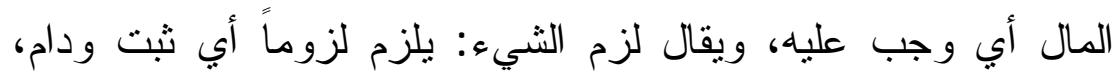
ويقال: لازمت الغريم ملازمة أي داومت ملازمته وتعلقت به (').

\section{r- تهريف الالتزام في اصطلاح الفقهاء:}

عرف الهالكية الالترام بأنه: إلزام الثخص نفسه شيئًا من المعروف أو معلقاً على شيء بمعنى العطية(؟)، كما بطلق ويراد به إله

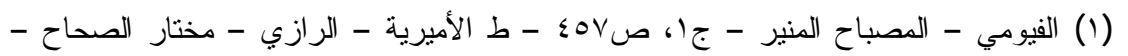

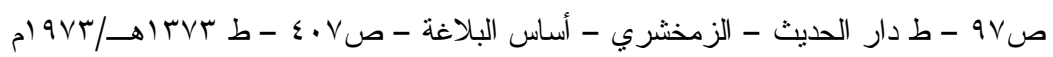

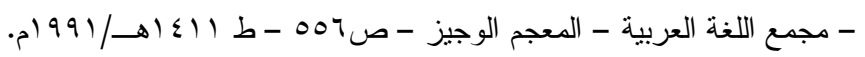

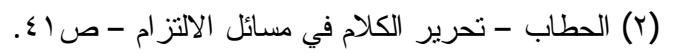




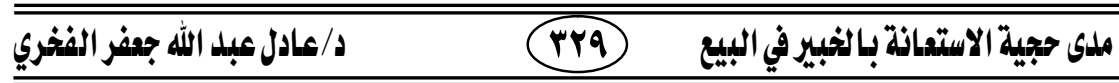

إلز ام المعروف بلفظ الالتز ام (')، وعرفه بعض المعاصرين بأنه: ترتيب

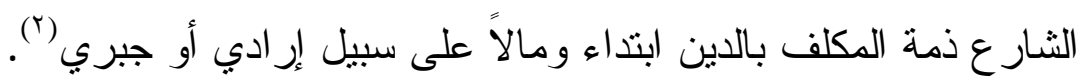

\section{ثانياً: طبيهة الالترام بالاستعانة بالخبير:}

الالتزام بإبداء الرأي قد يكون موضوعاً أساسياً ووحيداً في العقد يطلق عليه العقد الاستشاري أو عقود النصيحة كما يوجد التزام ثانوي بالنصح وهو التزام ضمني وهو في جميع العقود المهنية بما في ذلك

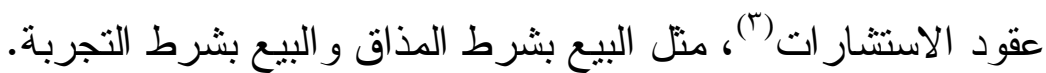

ثانيًا: نطاق الالترام بالنصيحة، وأثرها على علاقة الخبير بالمشتري في عقد البيع بشرط المذاق والتجربة:

\section{أولاً: نطاق الالترام بالنصيحة:}

مما تقدم عرضه من تعريف النصيحة نستطيع أن ننتهي إلى أن النصيحة في العقود الاستشارية لا تخرج عن كونها تقديم الر أي بالقيام بعمل أو عدم القيام به لمساعدة آخر بتوجيهه نحو اتخاذ القرار الصحيح بحثه وتحريضه على قبول المبيع أو رفضه بعد انتهاء مدة الخيار ، حيث يلتزم البائع في البيع بشرط المذاق، و البيع بشرط التجربة من تمكين الخبير من ذوف المبيع أو تجربته في المدة المحددة بحيث تتوفر الحرية المطلقة للمشتري من قبول المبيع؛ ومن ثم إتمام الصفقة - أو رفض بـ بـ (1) الثيخ/ عليش - منح العلي المالك في الفتوى على مذهب الإمام مالك - جا، صVY Y - ط الحلبي. (Y) د. عبد الله مبروك النجار - حدود مسئولية الددين المتضامن في الثريعة و القانون - رسالة

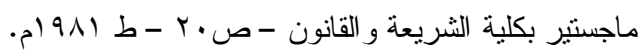

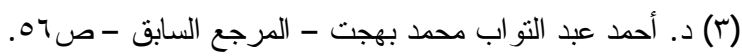




\begin{tabular}{|c|c|c|}
\hline العلدد الخامس عشر 10. Pم & rr. & محلــة اللدرابـة \\
\hline
\end{tabular}

المبيع، وليس للبائع أن يناقش الخبيرقبل تكوين رأيه، كما لا يجوز له الالتجاء إلى القضاء لإلز ام المشتري بقبول المبيع بعد إيداء الخبير رأيه بعدم صلاحية المبيع للغرض الذي يتم من أجله الثر اء (').

\section{ثانياً: أثر الالترزام بالنصيحة على علاقة الفبير بالاششتزي في وقدي البيع بشرط المذاق والتبربة:}

يتوقف مدى هذا الأثر على طبيعة النصيحة، هل مؤداها أن دور

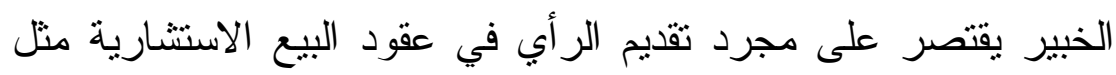
البيع بشرط المذاق، و البيع بشرط التجربة وينتهي كل دور له بعد ذلك؟

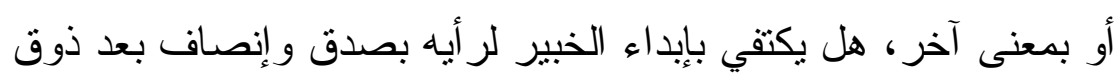

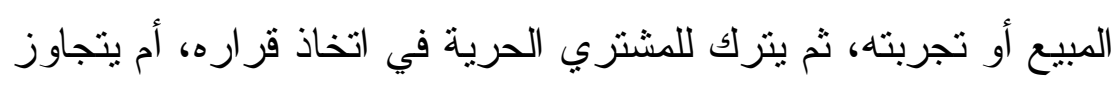
الخبير ذلك إلى حد تتفيذ الحلول المفترضة و إحلاله محل المشتري؟ في هذا اختلف الفقهاء ويمكن هصر الخلاف في قولين نمرضهـها فيما يلي:

\section{القهول الأول: - (القول}

ذهب الجمهور من المالكية و الثافعية و الحنابلة(؟)، إلى أن النصيحة ملزمة وقد نقل بعض فقهاء الحنابلة المتأخرين الإجماع على ولى دهاء

(1) د. ممدوح مبروك - أحكام العلم بالمبيع وتطبيقاته في ضوء نقدم وسائل التكنولوجيا المعاصرة

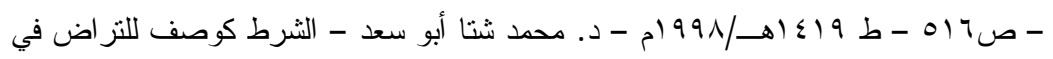

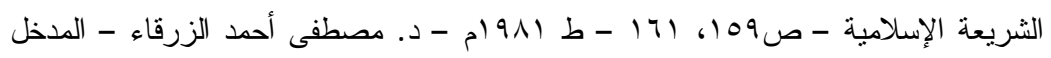

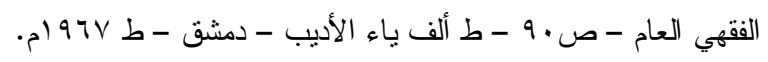

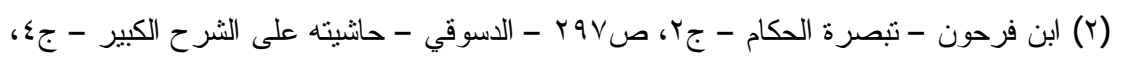

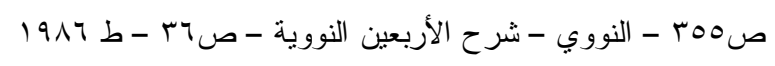




\section{ملى حجية الاستعانة بالخبير في البيع}

أن النصيحة ملزمة جاء في الحسبة "أن النصيحة ملزمة بإجماع السلف و علماء المسلمين بصرف النظر عن طبيعة الجزاء، و إن اختلفت الآر اء حول كيفية الالتز ام"(')، و لا يسمح المقام لعرض تفصيلات الفقه و آرائه في هذا الصدد، واكتفى بسرد بعض الأمثلة على أن النصيحة ملزمة ومنها:

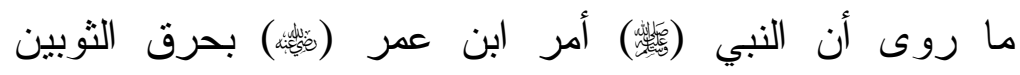

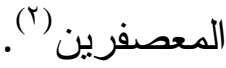

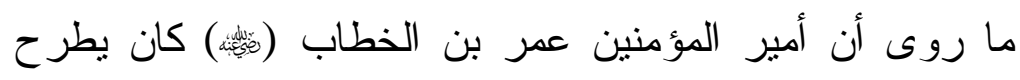
اللبن المغشوش في الأرض أدباً لصاحبه (َ).

\section{وجه الدلالة:}

أن الناصح في الآثار السابقة لم يكتف بمجرد إعطاء الرأي

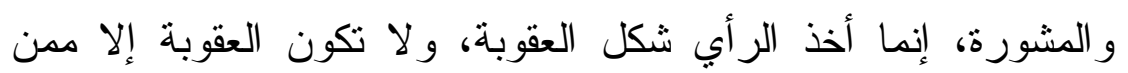
بملك الإلز ام.

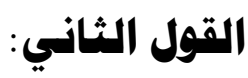

ذهب بعض المعاصرين إلى أن النصيحة في الأصل هي مجرد تقديم الرأي وأن علاقة الخبير بالمشتري في البيع بشرط المذاق و البيع بشرط التجربة يختلف باختلاف قصد المشتري من الاستعانة بالخبير ، فإن كان قصده هو مجرد الاستئاس برأيه و إرشاداته ونوجيهاته لأخذ بأن

$$
\begin{aligned}
& \text { (1) (ابن تيمية - الحسبة في الإسلام - صبح و وما بعدها. }
\end{aligned}
$$

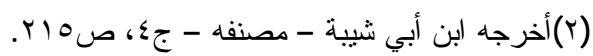

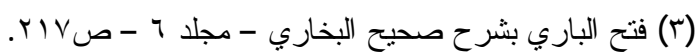




\begin{tabular}{|c|c|c|}
\hline العدد الخامس عشر 10بم & MrY & مجلـــة الدلدرايــــة \\
\hline
\end{tabular}

الحيطة واليقظة تجاه تصرف معين فهنا لا يتصور أن تكون النصيحة ملزمة، أما إن كان قصد المشتري الاستعانة بشخص ذا خبرة أو مجموعة من الخبراء قبل الإقدام على تتفيذ البيع لأخذ رأيهم و إتباعهم فهنا نكون أمام نصيحة ملزمة (1)

\section{التزجيجح:}

بعد عرض الآراء نستطيع القول بأن قول المعاصرين بنفي الصفة الإلز امية للنصيحة هو الأولى بالقبول و على ذلك يكون للمشتري

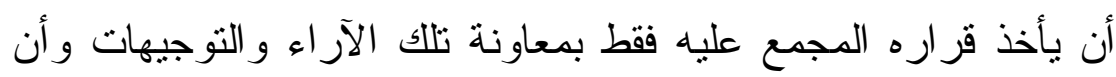
يتزك نفسه تتقاد لما تتوقف عليه ذاته من رغبة، و لا يسمح سوى لنفسها وما تتتهي إليه إر ادته الداخلية وميو لاته الطبيعية وتكون مهمة الخبير في هذا الثأن هي مساعدة المشتري على التروي والتدبر وعدم التهور و الانزلاق في اتخاذ القرار الذي لم يجمع عليه بعد(؟)، لكن هذا لا يمنع أن تصطبغ النصيحة بالصفة الإلز امية خاصة في مجال التطور الكبير

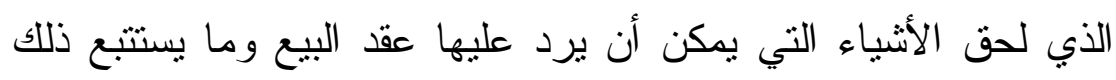
من نو اضع ومعارف وخبر ات المشتري العادي مما يدعو المشتري إلى الى

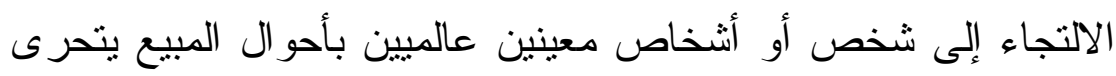
فيهم التخصص الفني الكبير، على أن يكون أساس هذه الصفة الإلز امية

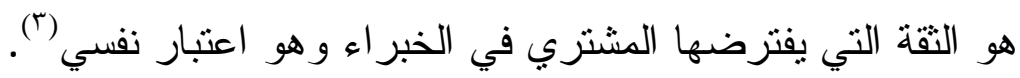

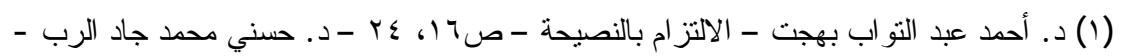

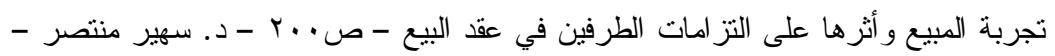

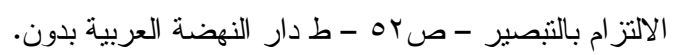

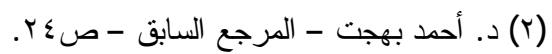

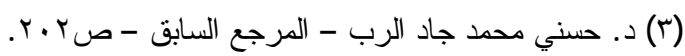




\begin{tabular}{|c|c|}
\hline العدد الخامس عشر 10+rم & مجلـة اللدرايــة \\
\hline
\end{tabular}

الفصــلـل الثـــاني

حجية الاستعانة الحبير، وطبيعة بد الخبير

على الشيء المبيع وموجبات مسُولية الخبير

عن المبيع، ومسفطات نالك المسوُلية 


\section{الإبمث الأول}

\section{همية الاستعانة بالخبير وطبيعة يده على الشيى المبيع}

\section{الإطابب الأول}

\section{همية الاستعانة بالخبير في البيـع بشرط المذاق، وبشرط التجربة}

لقد عد العلماء الاستعانة بالخبير للأخذ برأيه في البيع بشرط

المذاق و البيع بشرط التجربة بما يحقق مصلحة للمشتري أو دفع مفسدة عنه من الأمور المباحة شرعاً أو أنها نوع من الاستشارة المأمور بها، وأن تقديم النصيحة يدخل في باب الأمر بالمعروف والنهي عن المنكر، وقد قامت الأدلة دن الكتاب و السنة وفعل الصحابة والعرب و الإجماع

\section{على هشروعيتهـها: أولاً: الكتاب:}

أما الكتاب فآيات كثيرة منها:

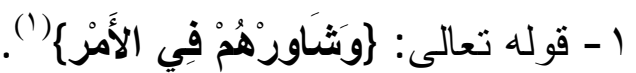

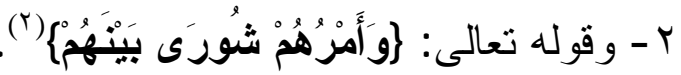

\section{وجهـ الدهالة:}

الآيتان صريحتان على الأخذ بالثورى في الأمور التي تحتاج إلى رأي، وظاهر الأمر في الآيتين للوجوب وحمله الثافعي على الثى الندب(َ)، وأن الله مدح الذين ينتاورون في الأمور قبل الإقدام عليها

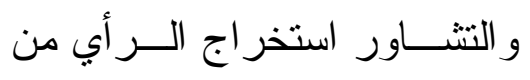

$$
\begin{aligned}
& \text { (1) سورة آل عمران - من الآية } 109 .
\end{aligned}
$$

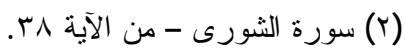

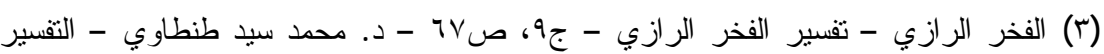

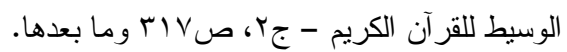




\begin{tabular}{|c|c|c|}
\hline العدد الخامس عشر 10بrم & rry & مجلـة الدرايـــة \\
\hline
\end{tabular}

الغير، قال الحسن ما تشاور قوم إلا هدو الأرشد أمور هم ').

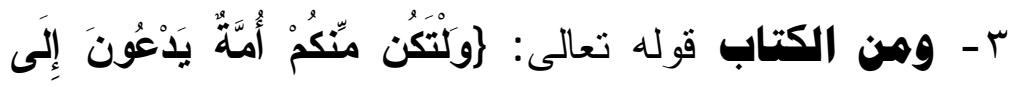

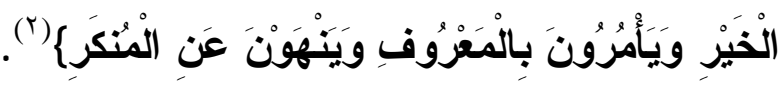

\section{وجبــه الدلالهـة}

فقد دلت الآية على أن من صفات المؤمنين الأمر بالمعروف

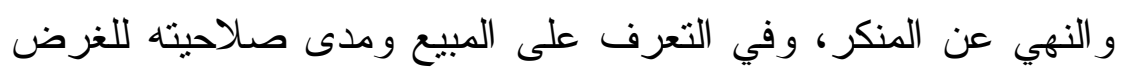
من شرائه بوسيلة مشروعة من المعروف المأمور به، والاستعانة بالخبير من هذا النوع، فتكون مشرو عة (r).

ثانياً: السنة الاطهرة: فمنها أحاديث كثيرة وأفعال تدل على مشروعية الاستعانة بالخبر اء بل والحث عليها في مجالات المعاملات و الاجتماعات و أمور السياسة و الحرب هنهـا:

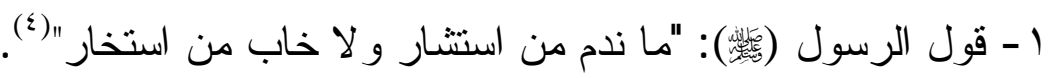

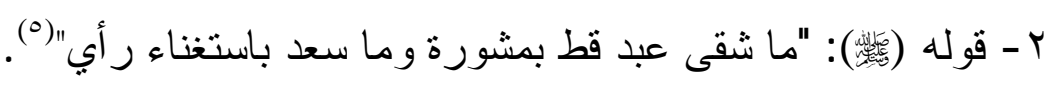
ب - كمــا استعان النبي (筑) بأهل الخبرة، فقد استعان بعبد الله بن أريقط

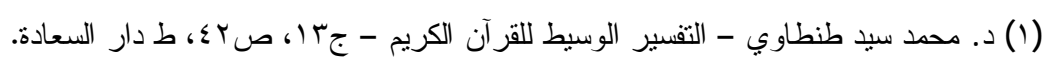

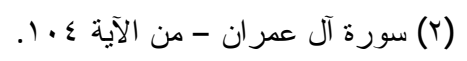

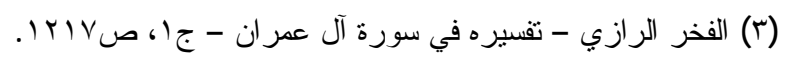

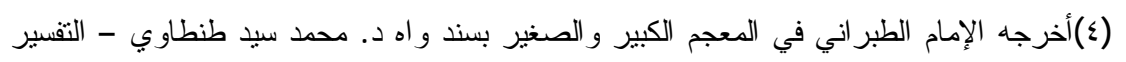

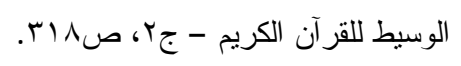

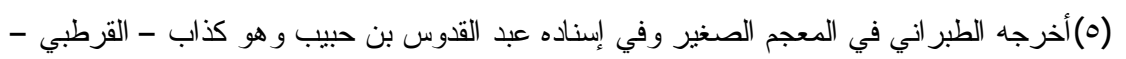

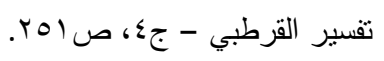




\section{ملى حجية الاستمانة بالغبير في البييع}

وكان مشركاً ليسلك به طريق غير معهود للمدينة(')، كما أنه دعا

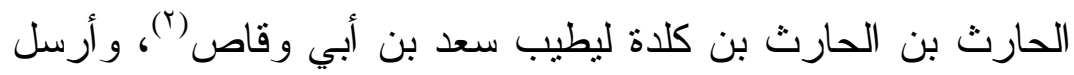

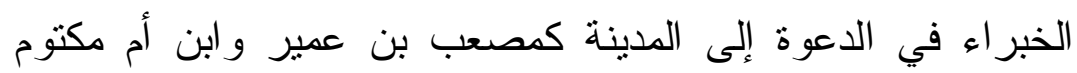
ليقر أ الناس العلم ويعلموهم أمور الدين (ماء.).

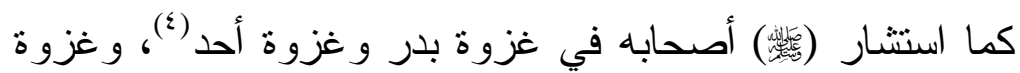

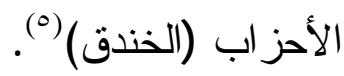

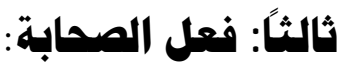

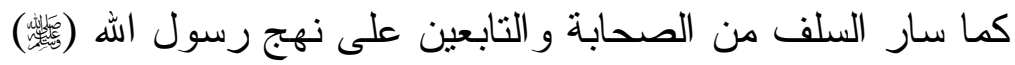
في الاستعانة بأهل الرأي والخبرة في الأمور التي تتعلق بمصالح المؤمنين وكانو ا يتشاورون في الأحكام واستتباطها من الكتاب و السنة

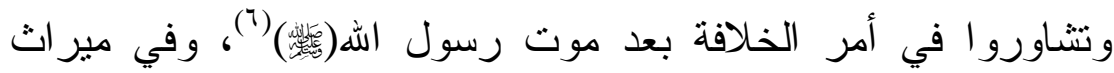

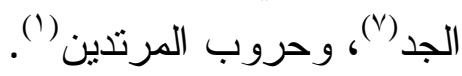

(1) د. مصطفى السباعي - السيرة النبوية دروس وعبر - صلr - ط دار الور اق ودار السلام - مهوار

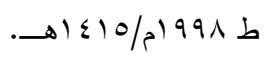

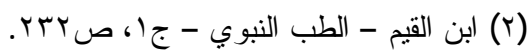

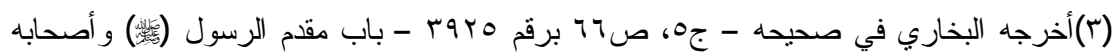
إلى المدينة.

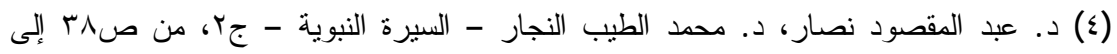

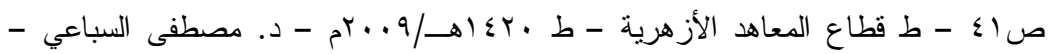

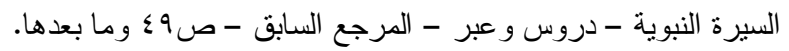

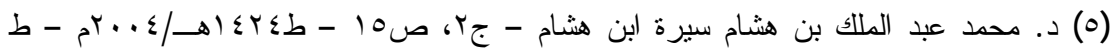
وزارة الأوقاف - المجلس الأعلى للشئون الإسلامية - مركز السيرة ولثام والسنة - لجنة السيرة - النبوية د. مصطفى السباعي - المرجع السابق - صه0 - د. عبد المقصود نصار - د. محمد

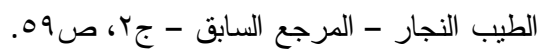

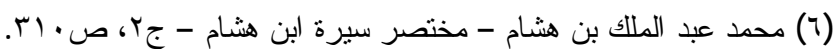

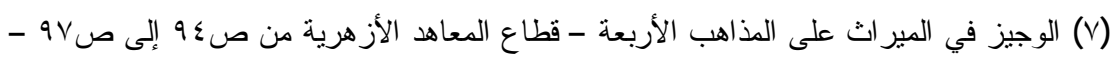

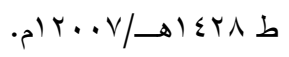




\begin{tabular}{|c|c|c|}
\hline العدد الخامس عشر 10بم & HrA & مجلــة الدرايـــة \\
\hline
\end{tabular}

قال البخاري: "وكانت الأمة بعد النبي (ل) يستشيرون الأمناء من

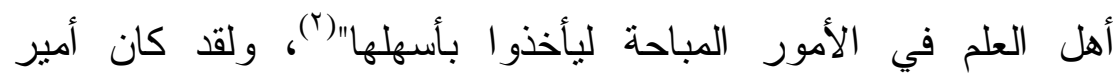

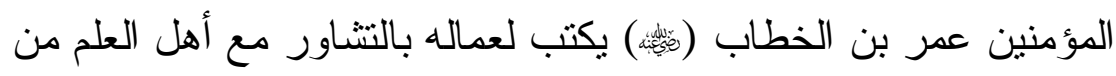
الر عية ويتمثل لهم في كتبه بقول الشاعر :

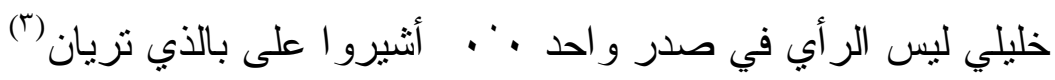
كما تمدح الحكماء و الثعر اء بمصلحة الثورى وما ينرتب عليها

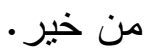
و من ذلك قول بثار بن برد:

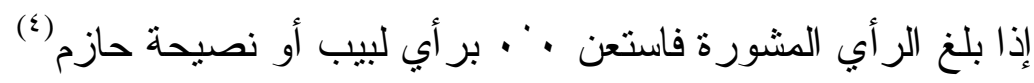

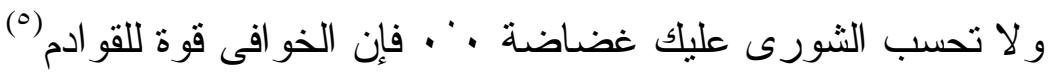

\section{رابعاً: الإجماع:}

إبداء النصيحة في مدى صلاحية المبيع للغرض من شرائه من

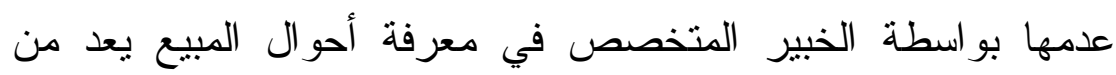
الأمر بالمعروف و النهي عن المنكر وهو من الواجبات، وقد نقل الإجماع على وجوبه غير و احد من علماء الأمة وجا".

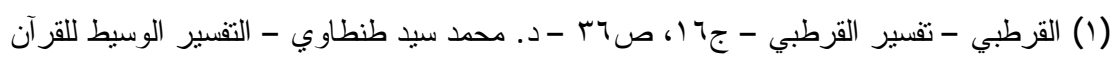

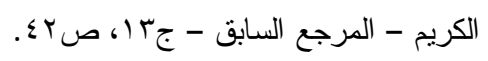

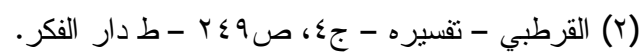

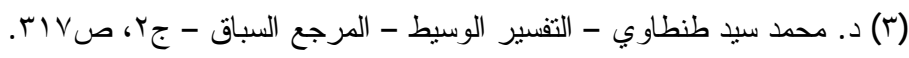

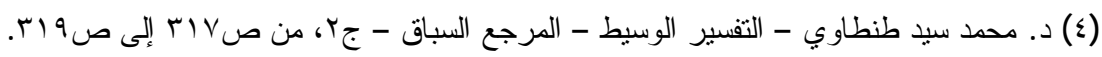

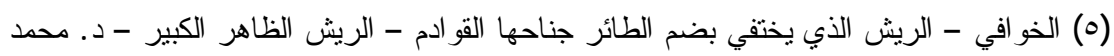

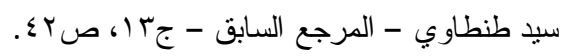

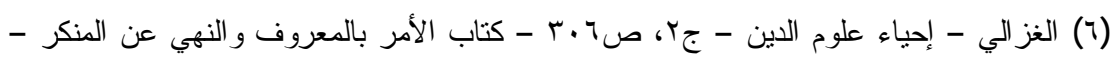

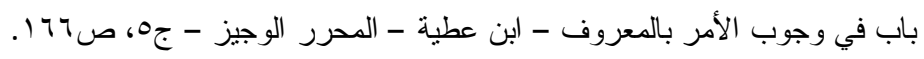




\section{د/عادل عبلد الله جعفر الفخري}

\section{ملى حجية الاستعانة بالخبير في البييع}

الاطلب الثاني

\section{طبيعة يد الخبير على همل التعاقد خلال مدة ذوق المبيع أو}

\section{تجربته}

لما كان قبض المشتري للمبيع خلال مدة المذاق أو التجربة يستتد إلى سبب شرعي وهو العقد، الذي بمقتضاه يلتزم البائع بتسليم المبيع للمشتري، والذي بدوره يعهد إليه إلى الخبير الذي يقوم بذوق المبيع أو

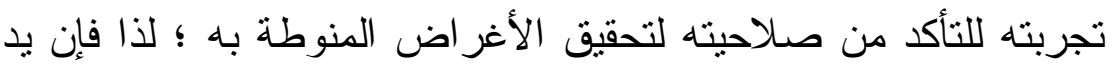
الخبير على الثيء محل التعاقد خلال تلك المدة تعد يد أمانة وقد عرفها الفقهاء بأنها: اليد التي تقبض الثيء بإذن مالكه(')، وقد تتاول الفقه الإسلامي أحكام يد الأمانة تحت مسمى الوديعة؛ لذا يستدعي المقام

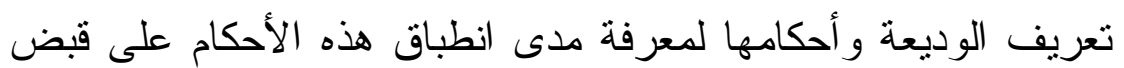
الخبير للمبيع خلال فترة المذاق أو التجربة وذلك على النحو التالي:

\section{أولاً: تعريف الوديعة في الفقه الإسلاهي:}

\section{ا - تعريف الودديعة لغة:}

الوديعة مأخوذة من ودع بمعنى تزك و إما مأخوذة من ودع بمعنى سكن، وذلك لأنها ساكنة عند الوديع فالإيداع في اللغة وضع الثيء عند غير صاحبه لحفظه (؟).

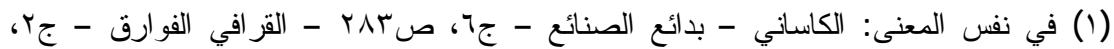

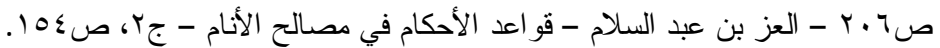

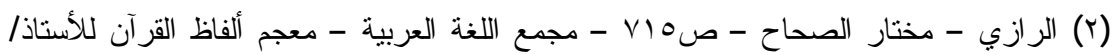

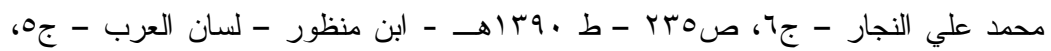




\begin{tabular}{|c|c|c|}
\hline العدد الخامس عشر 10+rم & res & مجلــة الدرايـــة \\
\hline
\end{tabular}

\section{r- تعريف الوديعة في اصطلاح الفقهاء:}

لقد تعددت عبار ات فقهاء المذاهب الإسلامية في تعريف

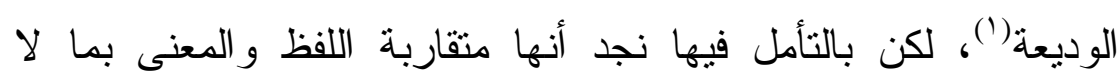
يخرج الوديعة عن كونها: نقل وتوكيل المالك أو نائبه حيازة المنقو لات إلى الغير لحفظها فكلمة (توكيل) قيد أول يخرج حيازة الغير للأشياء بدون توكيل فإنها تسمى سرقة أو غصباً.

ولفظ المنقو لات قيد ثان يخرج ما لا ينقل كالعقار و الدور وما لا ينقل فإن تسليط الغير عليهما لا يسمى وديعة وكلمة الغير لفظ عام

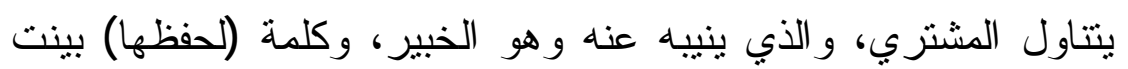

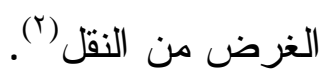

\section{ثانيًا: أحكام عقد الوديعة (يد الخبير على المبيع خلال مدة ذوقه أو تجربتهه):}

يرتب قبض الخبير للمبيع خلال مدة ذوقه أو تجربته التزامان

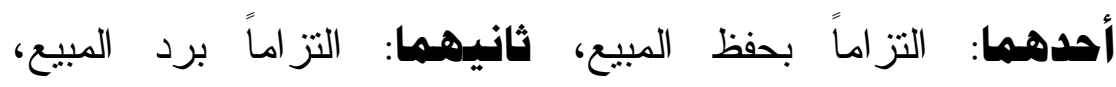
نمرضهما فيسما يلبي:

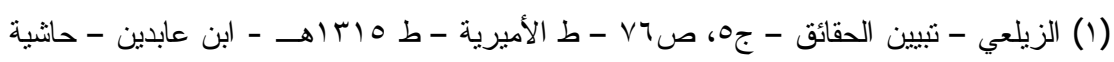

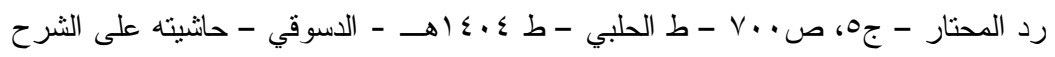

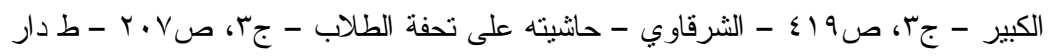

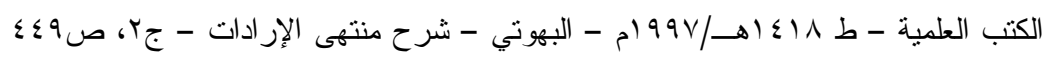

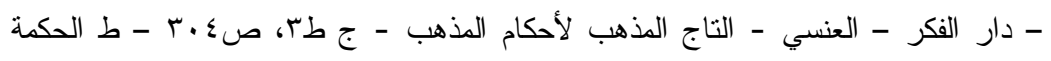

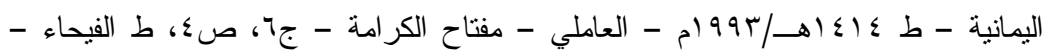

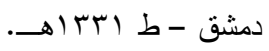

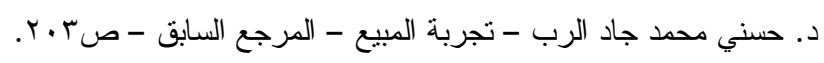




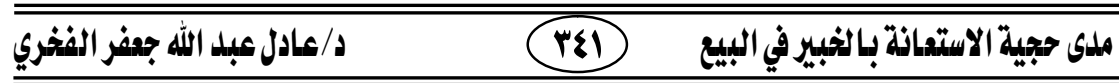

\section{أولاً: الترام الخبيز بمفظ المبيع خلال هدة ذوقه أو تجربته:}

\section{1 - تمريف الهمظ لغةت:}

يطلق الهفظ لغة ويراد به: رعاية الثيء وصيانته ومنعه من

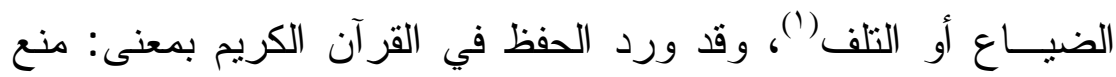

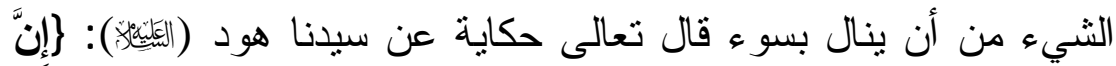

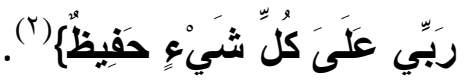
قال القرطبي في معنى الآية أن الله يحفظني من أن تتالوني

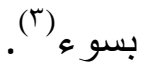

\section{r- تعريف الهنظ في اصطلاح الفقهاء:}

إن النصوص الفقهية المتعلقة بحفظ الأثياء التي تنتقل حيازتها إلى غير مالكها بناءً على عقد من العقود رغم إثشارتها إلى الحفظ لم

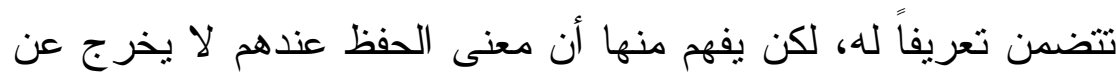

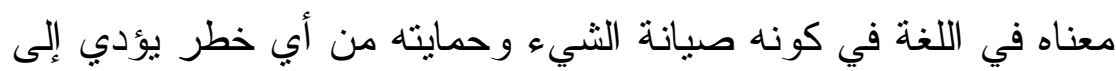
هلاكه أو النقص من قيمته(ع).

(1) الر ازي - مختار الصحاح - صع ا وما بعدها - ط دار الحديث - المعجم الوجيز - ص. ب -

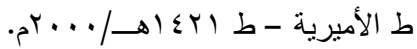

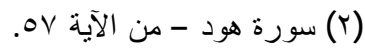

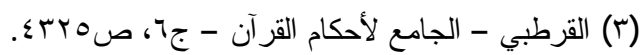

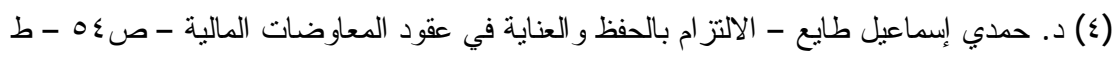




\begin{tabular}{|c|c|c|}
\hline العدد الخامس عشر 10بrم & rIS & مجلـة الدرايـــة \\
\hline
\end{tabular}

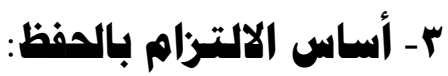

إن التزام الخبير بحفظ المبيع مدة ذوقه وتجربته يجد سنده في

الكتاب و السنة و الإجماع و المعقول.

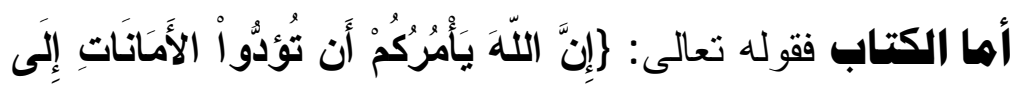

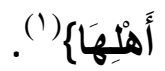

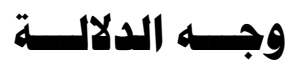

الآية صريحة في وجوب أداء الأمانات إلى أصحابها، و لا يتحقق الصاه

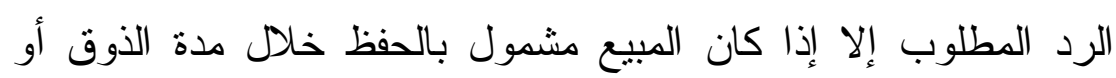
التجربة.

وأها السنة فنها حديث السائب بن يزيد حيث قال: قال رسول الله (أس عصا أخيه فليردها إليه"(؟).

\section{وجبـه الدلالهـة}

في الحديث أمر يرد ما أخذه الإنسان من غيره، و لا يتحقق الرد إلا بحفظ الثيء خلال مدة ذوق المبيع أو تجربته، وذلك بالإحالة بين المبيع وبين ما يؤدي إلى هلاكه أو إتلافه.

$$
\begin{aligned}
& \text { (1) سورة النساء - من الآية (1) }
\end{aligned}
$$

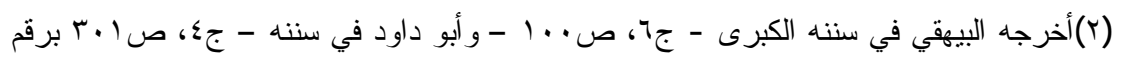

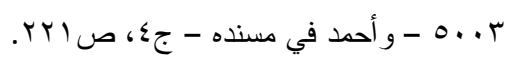




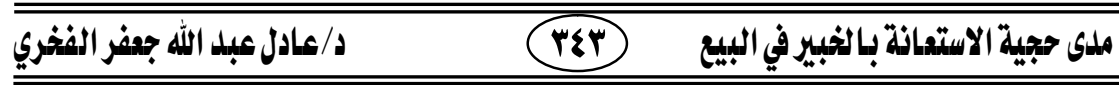

وأها الإجماع: فقد نقل القرطبي إجماع فقهاء الشريعة على وجوب رد الأمانات إلى أصحابها، ولا يتحقق الرد إلا بالمحافظة و الحيلولة بين الأمانات وبين ما يعتريها من هلاك أو تلف (1). وأها المهقول فإن الشريعة تهدف إلى المحافظة على المال وذلك من خلال الحث على تحصيله ابتداءً بالتكسب و العمل ومن خلال حمايته من العدوان عليه وبما يهدده بالزوال، ولذلك شرعت ما يكفل حفظه

و عدم إضاعته بالحجر على السفيه وحد السرقة ووجوب الضمان ().

\section{ع- خصائص الترام الخبير بهفظ المبيع خلال فتزة الذوق أو وحني}

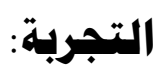

يتميز الالتز ام بحفظ المبيع عن غيره من الالتزامات بخصائص

منها أنه التز ام ببذل عناية و عمل و غير قابل للانقسام وسوف نعرضها فيسما يلي:

\section{أولاً: أنه التتزام ببذل عناية:}

تتطلب هذه العناية أن يقوم الخبير خلال مدة ذوق المبيع أو تجربته بجميع الأعمال اللازمة لكي يظل المبيع بالحالة التي قبضه هاته

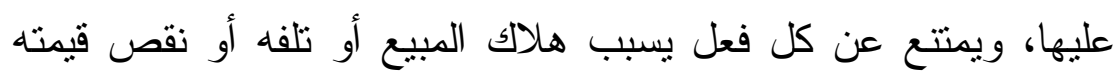

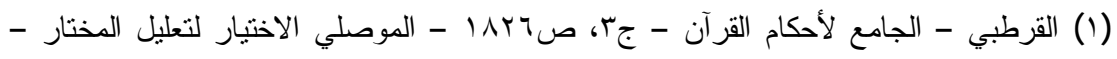

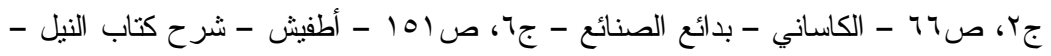

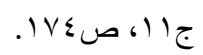

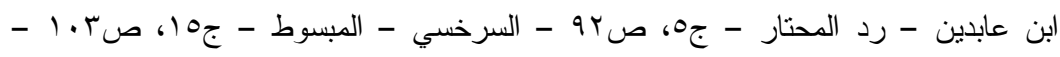

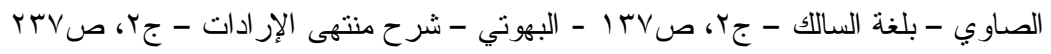

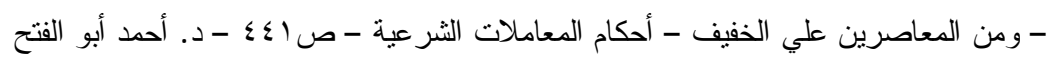

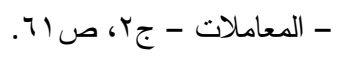




\begin{tabular}{|c|c|c|}
\hline العدد الخامس عشر 10بم & TIS & مجلــة اللدرايـــة \\
\hline
\end{tabular}

جاء في البدائع: "أنه إذا ضاعت - أي الوديعة - في يد المودع لديه بغير صنعه لا يضمن"(1)، وجاء في جو اهر الإكليل "هي - أي الوديعة

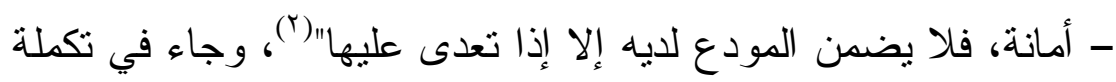

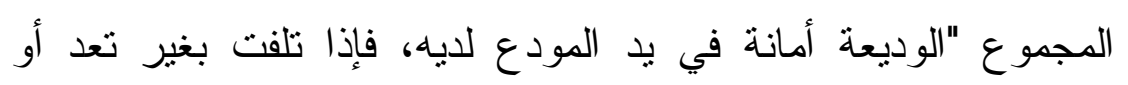
تقريط من المودع لديه فليس عليه ضمان"(").

يفهر من هذه النصوص أن الخبير يكون قد وفى بالتز امه إذا بذل في المحافظة على ما تحت يده كل ما يتطلبه بقاء المبيع بالحالة التي تسلمه عليها، وامتتع عن كل ما يسبب هلاك المبيع أو تلفه جاء في المغنى: "الوديعة أمانة، فإذا تلفت بغير تقريط من المودع لديه فليس

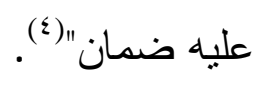

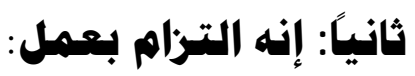

وهذا يتطلب أن يقوم الخبير بجميع الأعمال اللازمة لحفظ المبيع

خــــل

مدة الذوق أو التجربة وحمايته من التلف و الهلاك، فيجب عليه أن يضعه في حرز مثلاه، وأن يختبر المبيع الاختيار المألوف المتعارف بين أهل الصنعة، كما يتطلب من الخبير أن يمتتع من أي تصرف فيضر مئر بالمبيع الذي في حيازته فليس له أن يودع المبيع عند غيره إلا إذا كانت ضرورة تستدعي ذلك الإيداع كخوف حريق أو غرق أو خراب الحرز

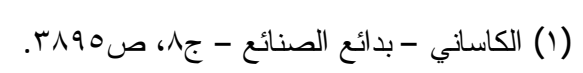

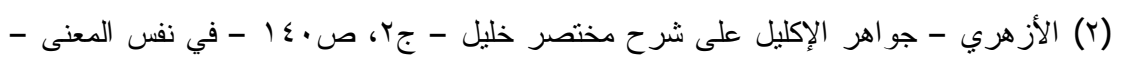

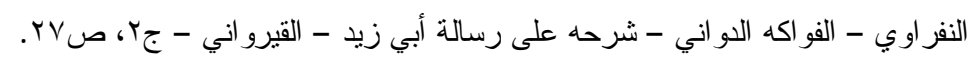

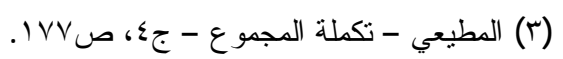

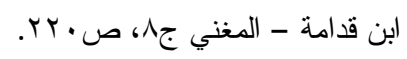




\section{د/عادل عبل الله جعفر الفخري}

ملدى جوية الاستمانة بالخبير في البييع

الذي يحفظ فيه، كما ليس له السفر بالمبيع إلا بإذن المالك، و إلا ضنمن (1)

\section{ثالثًا: أنه الترام غير قابل للانقسام:}

يخضع الالتزام للانقسام أم لغير الانقسام بحسب طبيعة محل العقد، فإذا تعدد الخبر اء وكان المبيع قابل للانقسام بطبيعته فإن الالنز ام بحفظ المبيع خلال مدة ذوق المبيع أو تجربته يكون قابلاً للانقسام بحيث يلتزم كل خبير بحفظ ما يقوم باختباره، أما إذا كان المبيع غير قابل للانقسام بطبيعته كما هو الغالب في موضوع دراستتا فإن الالتز ام بالحفظ لا يتجزأ ولا ينقسم كما لا يتجزأ إذا نص في العقد على عدم

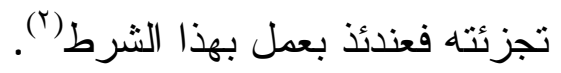

\section{ثانياً: الترام الخبير برد المبيع بعد ذوقه أو تجربته:}

يرتب عقد الوديعة التزاماً على عاتق الخبير مؤداه رد الوديعة

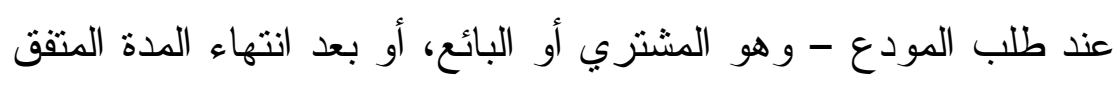

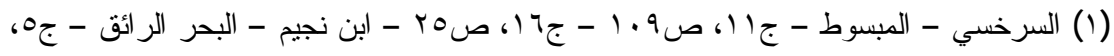

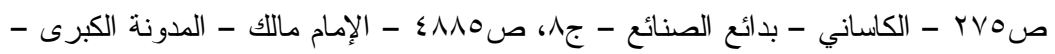

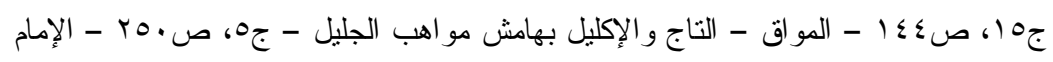

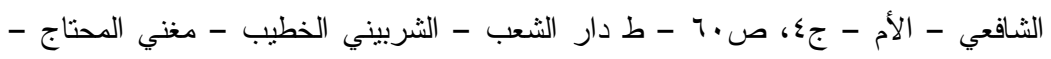

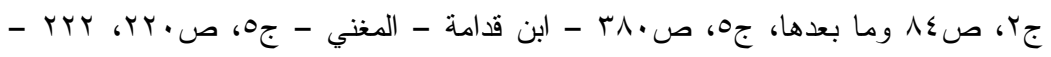

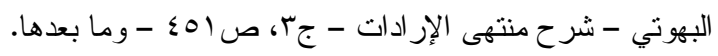

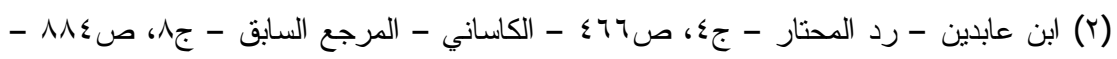

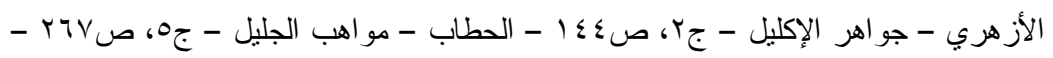

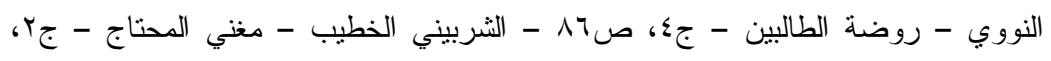

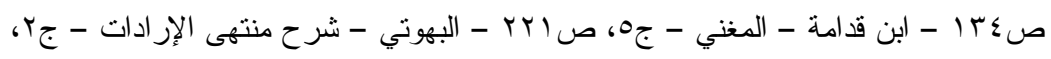

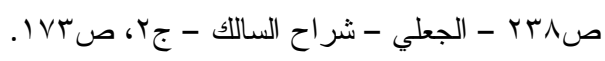




\begin{tabular}{|c|c|c|}
\hline العدد الخامس عشر 10بم & riY & مجلـة الدرايـــة \\
\hline
\end{tabular}

عليها للاختبار أو الذوق، وقد استدل الفقهاء و المفسرون على هذا الالتز ام بأدلة من الكتاب و السنة

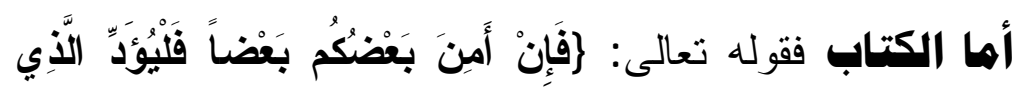

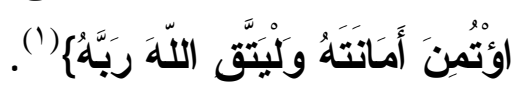

\section{وجبـه الدلالـة}

أن الهه تعالى أمر أمراً صريحاً كل من أؤتمن على أمانة أن يؤديها إلى صاحبها، و المبيع خلال فنرة ذوقه أو تجربته أمانة فيجب أنس ردها(r)

وأها السنة فنها حديث أبي هريرة عن النبي (先) أنه قال : أد الأمانة إلى من ائتمنك و لا تخن من خانك" (").

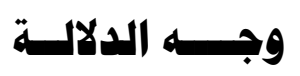

الحديث دل على أن كل من أؤتمن على أمانة أن يؤديها إلى صاحبها و لا يخن ولو على سبيل المعاملة بالمنل (ع).

$$
\begin{aligned}
& \text { (1) سورة البقرة - من الآية rیمب. }
\end{aligned}
$$

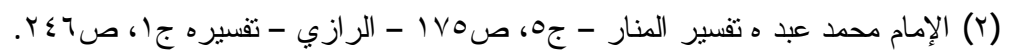

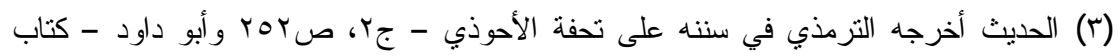

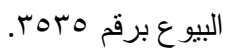

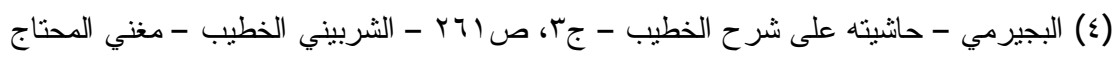

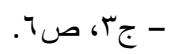




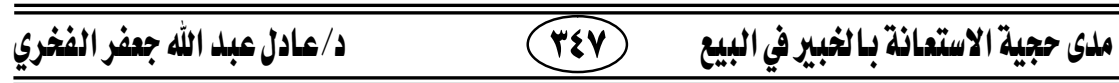

المبحث الثاني

أسباب هسئولية الخبير خلال فترة ذوق المبيع أو تجربته،

\section{ومسمقطاتها \\ الإطلب الأول}

\section{أسباب مسئولية الخبير خلال هدة ذوق المبيع أو تجربته}

إن حيازة الخبير للمبيع خلال فتزة ذوقه أو تجربته توجبه

الضمان عن الخطأ التقصيري، فمتى خالف الخبير ولم يبدي النصيحة

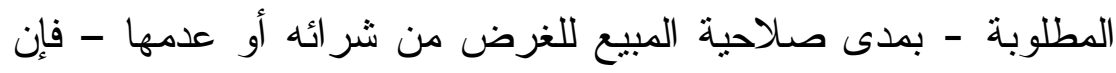

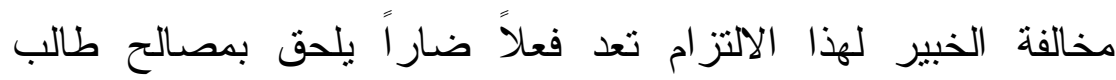
النصيحة بالضرر توجب الضمان بصرف النظر عن حدوث ضرر فعلي أم لا (')، كما يجب الضمان بسبب الخطأ التقصيري بعدم تتفيذ

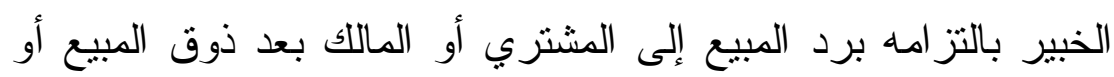
تجربته حتى ولو كان الخبير حسن النية ولو لم يصدر منه أي خطأ(؟).

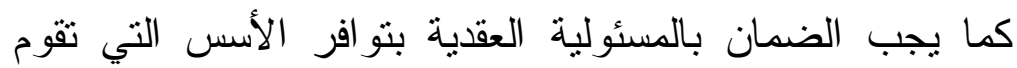

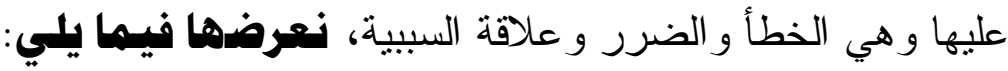
أؤلاً: الخطـأ:

الخطأ ضد الصواب(") آ، جاء في لسان العرب "أخطأ يخطئ إذا سلك سبيل الخطأ عمداً أو سهو ا"(๕)"، وفي اصطلاح الفقهاء يطلق الخطأ

$$
\begin{aligned}
& \text { (1) د. أحمد عبد التو اب محمد بهجت - الالتز ام بالنصيحة - المرجع السابق - صل (Y)، هr. }
\end{aligned}
$$

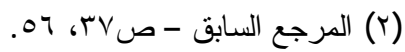

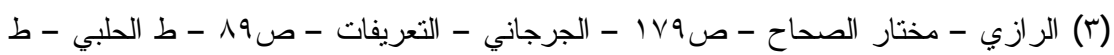

$$
\begin{aligned}
& \text {. THOV }
\end{aligned}
$$

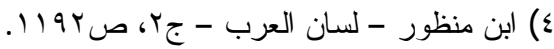




\section{العدد الغامس عشر 10 مr م}

وير اد به الإهمال وهو فعل يصدر عن الخبير بغير قصده بسبب نزك التثبيت عند مباشرة أمر مقصود (1).

كما يطلق وير اد به نوع من التعدي و التصرف في شيء فئ بغير

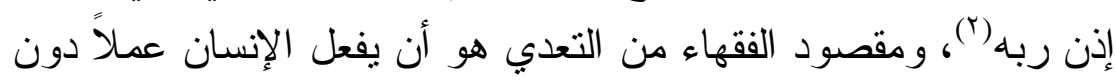

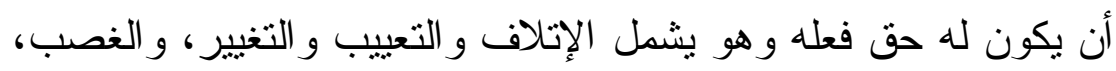
ووضع البد دون حق وبغير إذن المالك، فكل ذلك منن قبيل التعدي

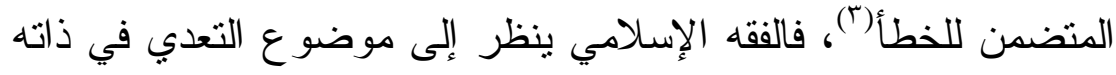

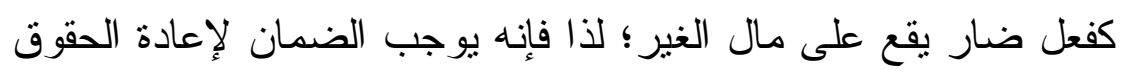
لأصحابها إذ الجوابر مشروعة لجلب ما فات من مصالح و الزواجر مشروعة لدرء المفاسد (ع)، و لا يشترط أن يكون من وجب علب عليه الضمان

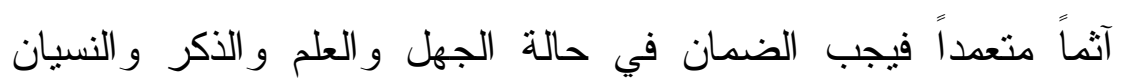
وعلى المجانين و الصبيان (o).

\section{ثانياً: الضـرو:}

بطلب الضرر لغة ويراد به كل أذى أو مكروه(ج)، جاء في

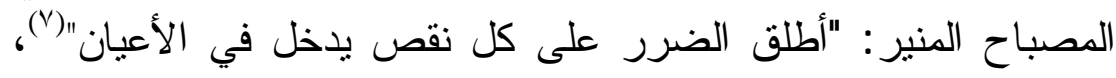
ومثل له بعض المالكية بقوله: "وقوع الضرر على الغير كنقصان حقه

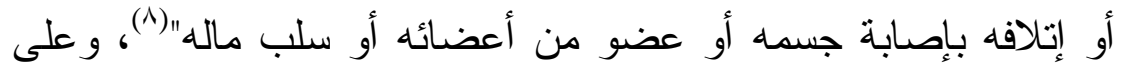
ذللك يسأل الخبير عن إضراره بالمبيع فيما يسبب خسارة فيه، سواءً

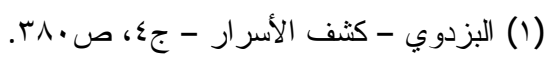

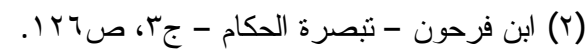

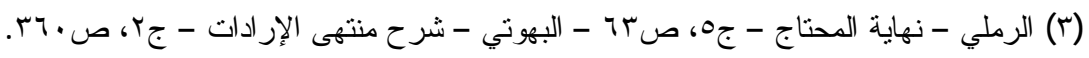

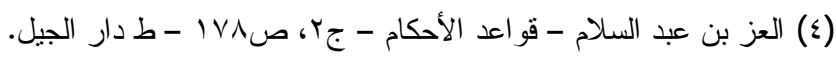

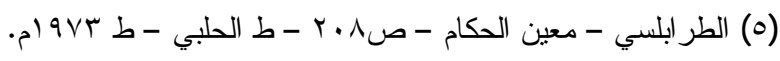

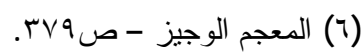

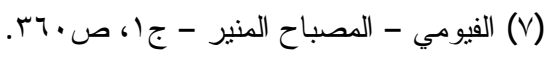

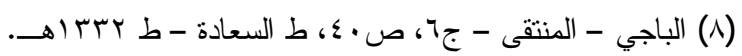




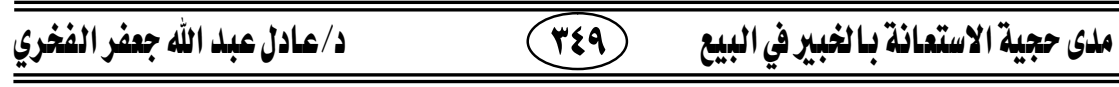

أكانت هذه الخسارة ناتجة عن نقص في ذات المبيع أو نقص منافعه أو

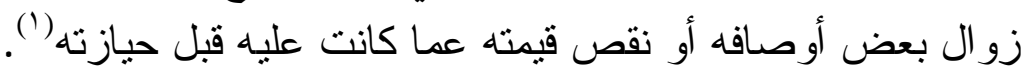
ويعد الضرر القوة المؤثرة في ايجاب الضمان على الخبير ، فئه فإذانها

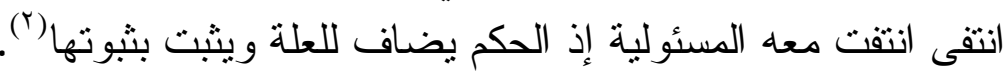

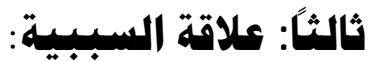

لا يكفي لوجوب مسئولية الخبير عدم تتفيذه لالتز امه بحفظ المبيع

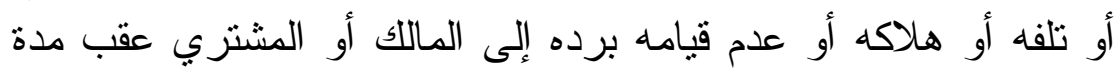

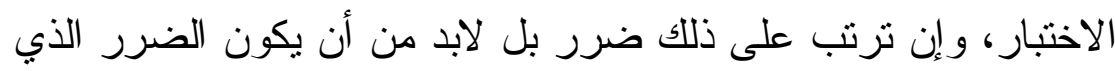

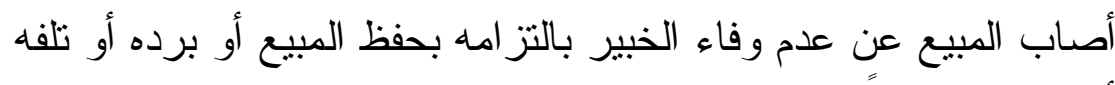

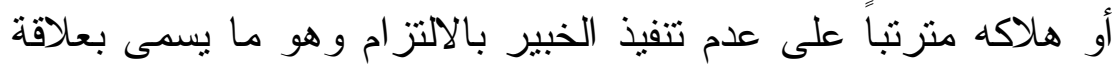

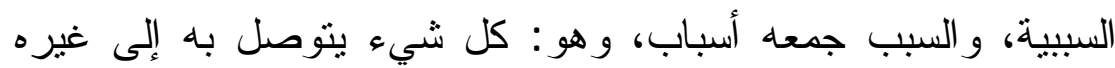

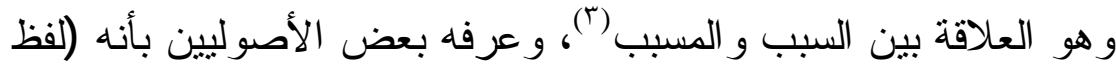
عام) يطلق على العلة وعلى السبب المصطلح. يقال البيع سبب الملك ولك البك

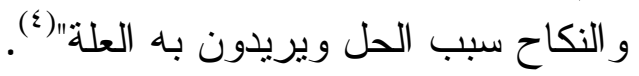

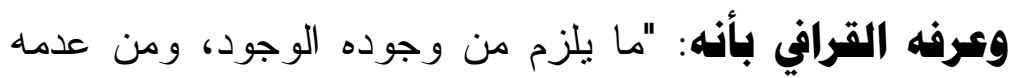

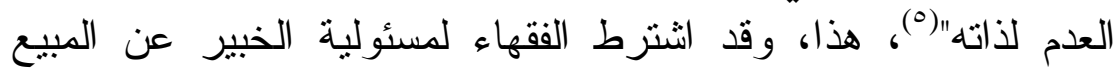
خلا فترة الذوق أو التجربة تو افر الرابطة السببية بين فعل الخبير

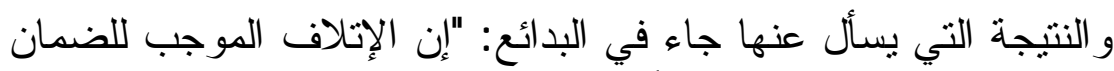

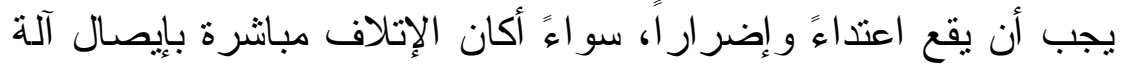

$$
\begin{aligned}
& \text { (1) في نفس المعنى - علي الخفيف - المرجع السابق - ص7؟ - د. مصطفى أحمد الزرقاء - }
\end{aligned}
$$

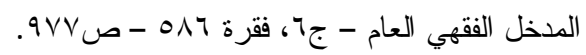

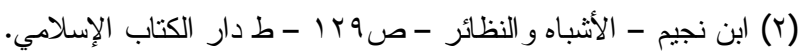

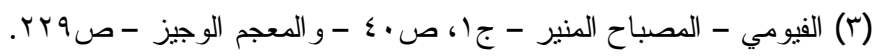

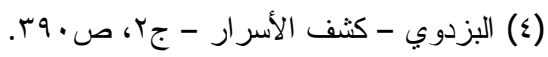

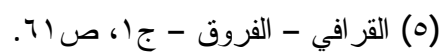




\begin{tabular}{|c|c|c|}
\hline العدد الخامس عشر 10 Prم & ro. & مجلـة اللدرايـــة \\
\hline
\end{tabular}

التلف بمحله أم تسبباً بالفعل في محل يفضي إلى تلف غيره حسب (العادة) (1)

\section{الاطلب الثاني}

\section{مسقطات وهوانع هسئولية الخبير عن المبيع خلال هدة الذوق أو التجربة}

لا يكفي لتحقق مسئولية الخبير عن المبيع خلال مدة ذوقه أو

تجربته تو افر الأسس التي تقوم عليها المسئولية، فقد ثتو افر هذه الأسس ولكن المسئولية لا تجب؛ وذلك عند نو افر مانع من موانع هذه المسئولية وهو ما يعبر عنه بالسبب الأجنبي الذي لابد للخبير فيه، ومن صور السبب الأجنبي الذي يسقط الضمان عن الخبير في الفقه الإسلامي القوة

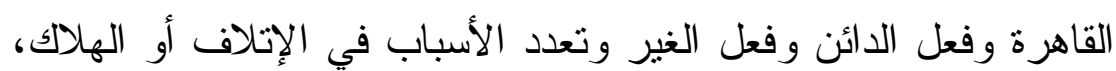
وسوف نهرض ذلك فيهما يلي: أولاً: القوة القاهرة أو الحادث الفجائي:

جاء عن الثافعية: "إذا تلف المبيع بآفة سماوية إنفسخ البيع وسقط

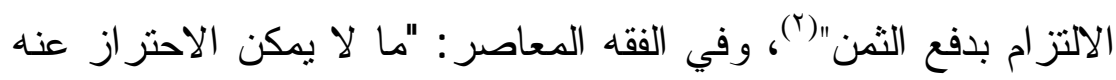

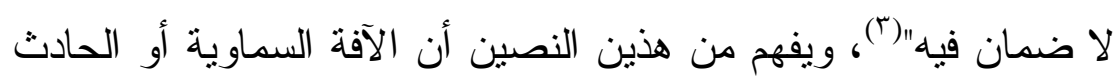
الفجائي الذي لابد للحائز فيه يسقط الضمان وينطبق هذا على الخبير الحائز للمبيع. 


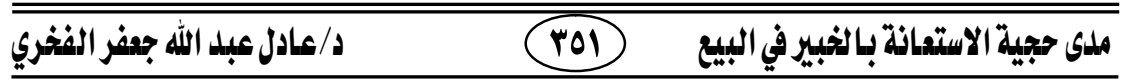

\section{ثانيًا: فعل الدائن "المالك أو المشتزي":}

قرر جمهور الفقهاء أن الدائن "المالك أو المشتري" إذا تسبب في

تلف وهلاك الشيء وهو في حيازة الغير - كالخبير في محل دراستتا

فإنه ليس لله الحق في الضمان مادام أنه كان باستطاعته عدم الهلاكي (').

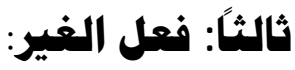

جاء عن الفقهاء ما يدل على أن التلف أو الهلاك بسبب فعل الغير يسقط الضمان عن الحائز وهو الخبير جاء في مجمع الضمانات "مكار (؟)، استقبله اللصوص فطر ح الحمل وذهب بالحمار، أو عجز عن تخليص الحمل منهم، و علم أنه لو حمله أخذ بعض اللصوص الحمل أو الحمار ، لا يضمن إذا ترك الحمل مع القدرة عليه"(『).

وجاء عن الشافهية: "إن إتلاف الأجنبي المبيع لا بفسخ البيع، بل يتخير المشتري بين أن يجيزه ويلزم الأجنبي البدل أو أن يفسخ،

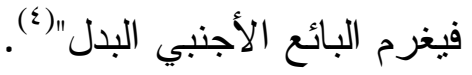

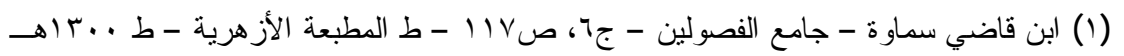

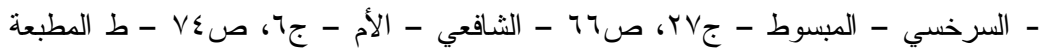

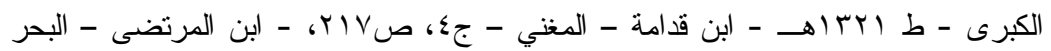

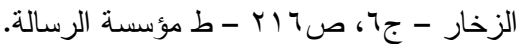
(r) المكار هو الذي ينقل المتاع من مكان لآخر نظير أجر معلوم.

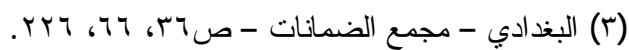

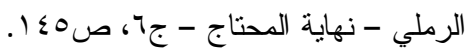




\begin{tabular}{|c|c|c|}
\hline العدد الخامس عشر 10بم & rOY & مجلــة اللدرايـــة \\
\hline
\end{tabular}

\section{رابعًا: تعدد الأسباب: - n}

\section{فرق الفقهاء بين حالتين:}

إحداهـها: إذا كان فعل محدثي الضرر ذا طبيعة واحدة، كما إذا اشترك جماعة في إتلاف شيء فإنهم يضمنون المثل أو القيمة، وهذا ينطبق في محل دراستتا كما إذا اثتنرك مجموعة من الخبراء في التعرف على المبيع وصفاته ثم هلك المبيع في أيديهم فإنهم يشتركون في مي مئري الضمان ويتحمل كل واحد نصيبه، كأن يكون أحدهما مباشر اً و الآخر متسبياً (1)

ثانيدهما: إذا اختلف عمل محدثي الضرر كأن يكون أحدهما مباثر اً والآخر متسبباً في إلحاق الضرر بالمبيع وفي مجمل در استتا كأن يكون الخبير هو الذي يقوم بحفظ المبيع وباختباره و اشترك معهد آخر كان سبباً في إلحاق الضرر بالمبيع، فاستثناءً من قاعدة تقديم

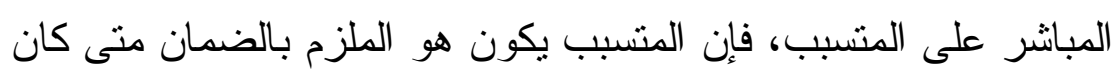
هو العامل الأهم في إحداث الضرر (r).

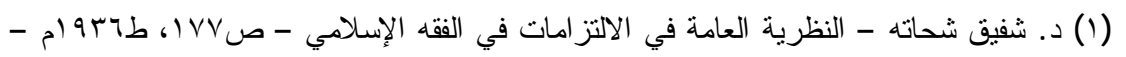

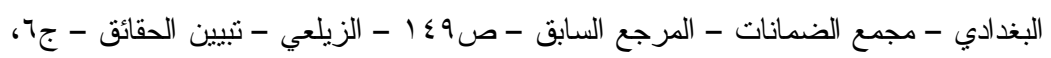

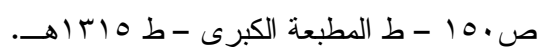

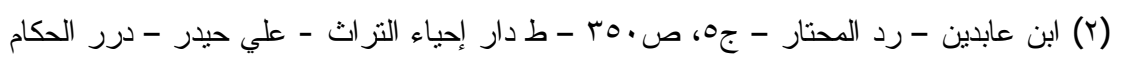

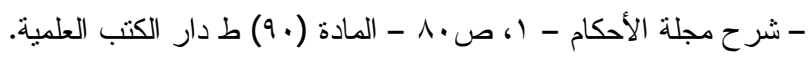




\section{د/عادل عبل الله جهفر الفخري}

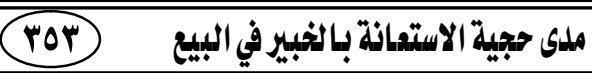

\section{الخــاتمبة}

وتشتمل على أهم النتائج، و التوصيات وفهرس المر اجع وفهرس الموضو عات.

\section{أولاً: أهم النتائج:}

بعد الرحلة العلمية في بطون الكتب الفقهية القديمة و المعاصرة،

\section{يمكن أن نورد النتائج التي توصل إليهها البهث فيها يلي:}

1 - أن الخبير هو: كل شخص صاحب اختصاص وكفاءة علمية

عالية قادر على تكوين الرأي السديد في الأمر الذي يستشار فيه، وأن لر أيه دور هام في تكوين الرضا الصحيح بالصفقة.

r - أن الاستعانة بالخبير تمثل أهمية كبرى في التعرف على

كنهة المبيع، ومدى صلاحيته وملاءمته لمدى حاجة المشتري من الثر اء.

r - أن محل الاستعانة بالخبير في العقود التي لا يكون للشخص

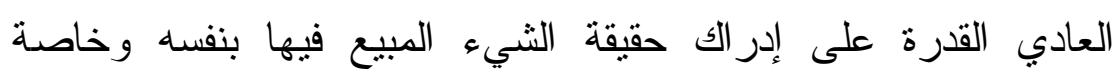
المبيعات ذات التقنيات الحديثة في صناعتها أو بيان مدى صالحيتها للغرض من شرائها ومن أمثلتها البيع بشرط المذاق و البيع بشرط التجربة.

ع - أن اشتر اط المشتري ذوق المبيع يعتبر من الأوصاف المقترنة بالتز اضي في هذا العقد و التي تعدل التز امات الطرفين فيه، إما بالقبول بعد إبداء الخبير رأيه بصلاحية المبيع، أو الرفض بعد قرار 


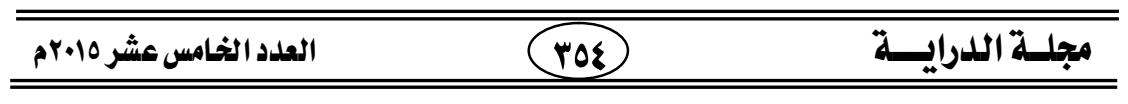
الخبير بعدم الصلاحية، وأن هذا البيع بندرج تحت خيار الرؤية وهو خيار محدد بمدة ذوق المبيع و إبداء الر أي فيه.

0 - أن البيع بشرط التجربة بيع يحتفظ المشتري فيه بحقه في تجربة المبيع لمعرفة مناسبته، ومدى صلاحيته للغرض الذي أعد لله، وهو يندرج تحت خيار الثرط المحدد بثلاثة أيام أو أكثر إن احتاجت التجربة للزيادة.

7 - أن شرط الاستعانة بالخبير عند إبرام العقد يعد من الثروط

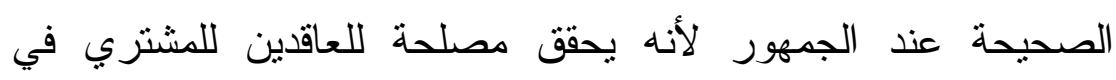
التعرف على حقيقة المبيع حتى يقدم على الثر اء على بصيرة، وللبائع في إتمام الصفقة متى حظي المبيع برأي الخبير بالصلاحية. V - أنه يجب أن يكون الخبير ذو علم وكفاءة عالية في حقيقة المبيع الذي يبدي الرأي فيه، وأن يكون متابعاً للتقدم العلمي في مجال

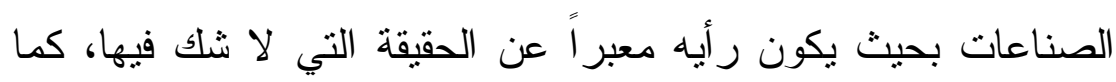
يجب أن يكون صادقاً فيما يخبر به الطرفين، وأن يكون حسن النية أميناً لا يميل لأحدهما لغرض مالي أو دنيوي، كما يجب عليه أن بستعين بغيره من الخبر اء على سبيل الاستئناس متى اشتبه عليه الأمر أو شك لأك

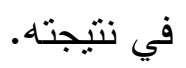

A - أن الخبير ناصح و النصيحة هي الرأي الذي يبدي إلى شخص ما بشأن ما يجب أن يفعل إما بالقيام بعمل بتمنل في قبول المبيع، أو عدم القيام به ويتمنل في لسان رفض إتمام الصفقة. 


\section{د/عادل عبل الله جعفر الفخري}

9 - أن النصيحة هي مجرد إبداء رأي كما سبق؛ لذا فهي ليست ملزمة، فلمشتري أن يأخذ قراره المجمع عليه بالقبول أو الرفض بمعاونة تلك الآر اء و التوجيهات، ويكون رأي الخبير لمجرد الاستثناس. • 1 - أن يد الخبير على الثيء المبيع خلال مدة الاختبار يد أمانة تتطلب منه القيام بحفظ ما في حيازته ورده بعد الاختبار فإن امتتع عن

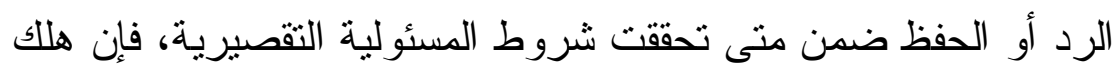
المبيع أو تلف أو سرق أو غصب بسبب إهمال الخبير ضمن، منى تحققت شروط المسئولية العقدية كما يضمن بقدر نصيبه إذا تعددت أسباب الهلاك لكن هذه المسئولية تسقط بسبب الأجنبي الذي بتمنت في لتركي القوة القاهرة أو الحادث الفجائي وفي فعل المالك أو المشتري أو فعل

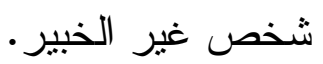

\section{ثانياً: أهم التوصيات:}

1 - نهيب بكل شخص يقلم على شراء شيء من الأشياء التي في تطور دائم بسبب التقدم التكنولوجي أن يستعين دائماً بالخبر اء من أهل الخبرة و الكفاءة العالية ذوي الاختصاص في معرفة حقيقة هذا الثيء الذي يقدمون على شر ائه.

r - نهيب بالدولة أن تهتم بما وصل إليه العالم من تقدم في مجال

الصناعات وذلك عن طريق توسيع مجالات البحث العلمي وأن نرسل البعثات العلمية للتعرف على التقافات الأجنبية المتطورة لتوفر الخبر اء القادرين على كثف حقيقة ما يستورد من دول العالم لإبداء الرأي في صلاحيتها أو عدمه. 


\begin{tabular}{|c|c|c|}
\hline العدد الخامس عشر 10بم & roy & مجلــة اللدرايـــة \\
\hline
\end{tabular}

\section{وختساهًا}

في نهاية هذه الرحلة العلية، فإني استسمح كل ناظر في بحثي

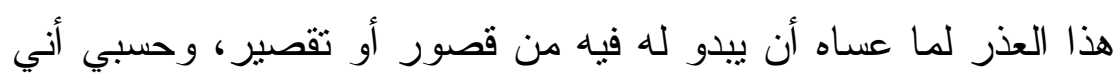

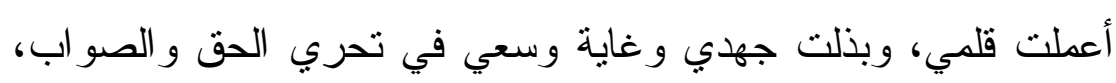

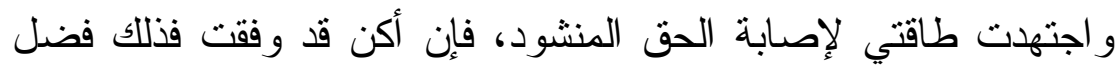

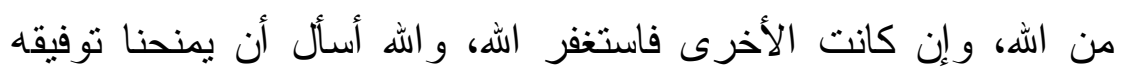

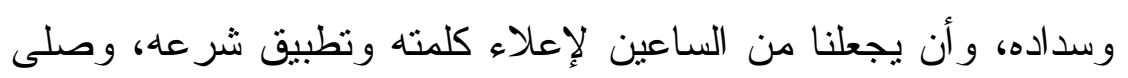

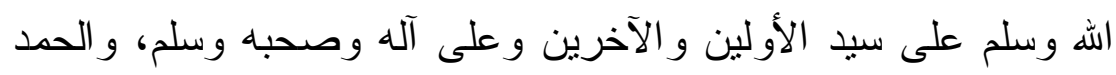
الله رب العالمين عدد خلقه ورضاء نفسه، وزنة عرشه، ومداد كلماته.

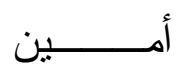




\begin{tabular}{|c|c|c|}
\hline ه/عادل عبل الله جففر الفغري & rov & ملى حجية الاستمانة بـالخبير في البيي \\
\hline
\end{tabular}

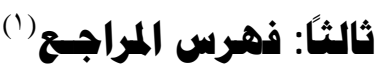

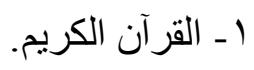

ـ أحمد: أحمد بن محمد بن حنبل المتوفى سنة إ؟ هـ - هسنده المسمى

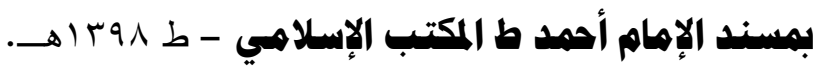

- أزهري: صالح عبد السميع الأبي الأزهري - جواهر الإكيل على هذتصر

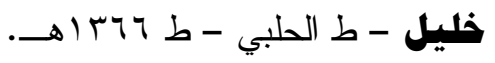

ـ أطفيش: محمد بن يوسف بن عيسى العدوي الجزائري المتوفى سنة بrس اهـ -

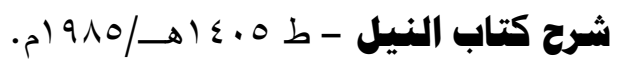

- باجي: سلمان بن خلف بن سعد المتوفى سنة ؟9 ؟ـــ - المنتقى شرح الموطأ

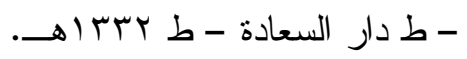

- بار : محد البار - المسئولية الطبية وأخلاقيات الطبيب.

- بجيرمي: سليمان بن محمد بن عمر البجيرمي المتوفى سنة ابY هـ - حاشيته على شرح الفطيب - ط المطبعة الكبرى.

- بخاري: محمد بن إسماعيل بن إبراهيم بن المغيرة المنوفى سنة بrorهـ -

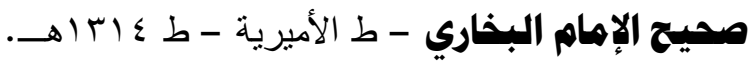

ــ بزدوي: علي بن محمد بن الحسين بن عبد الكريم البزدوي المنوفى سنة بمءـهـ

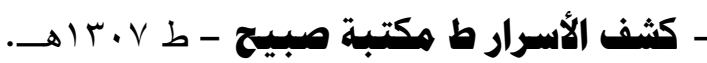

- بسيوني: أحمد البسيوني - قبسات هن السنة - ط ب أب ام.

- بغدادي: محمد بن غانم محمد المتوفى سنة . ب. اهـ - هبمع الضمانات -

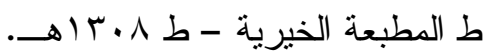




\begin{tabular}{|c|c|c|}
\hline العدد الخامس عشر 10 10م & rOA & مجلـة اللدرايـــة \\
\hline
\end{tabular}

- بهجت: أحمد عبد التواب محمد بهجت - الالترام بالنصيحة في هبال

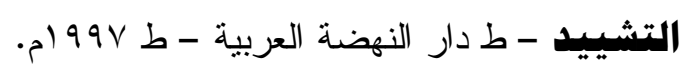

- بهوتي: منصور بن يونس البهوتي - المنوفى سنة .0. إهـ - كثاف القناع

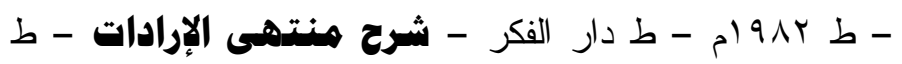
دار الفكر - الروض المربع - ط دار إحياء الكتب.

- بوصبري: أحمد بن أبي بكر البوصيري - المتوفى سنة ـ.دهــ - اتحاف

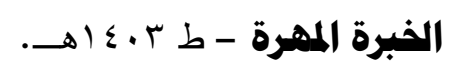

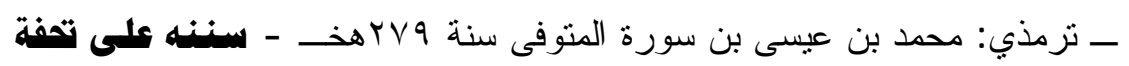

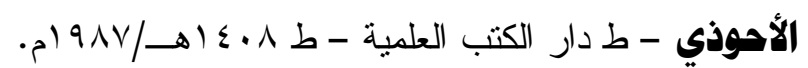

- تيمية: أحمد بن عبد الحليم بن عبد السلام ابن تيمية المتوفى سنة لVYAه -

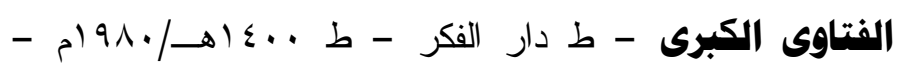

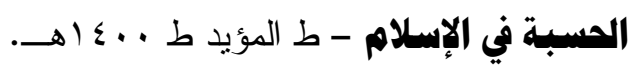

- جاد الرب: حسني محمد أحمد جاد الرب - تجربة المبيع وأثرها على

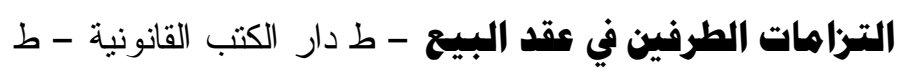

$$
\text { . } r \text { r. }
$$

- جبعي: زين الدين الجبعي العاملي - المتوفى سنة 970هـ - الروضة البهية - ط دار العالم الإسلامي - بيروت.

$$
\text { - جعلي: سراج السالك. }
$$

ـ جوزيه: شمس الدين عبد الله بن القيم الجوزية المنوفى سنة اله هـ - إعلام

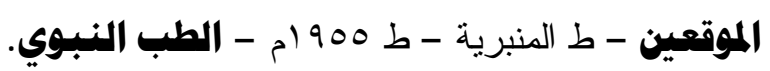

ـ حاج: هاني الحاج - هختصر تفسير ابن كثير - ط المكتبة النوفيقية. 


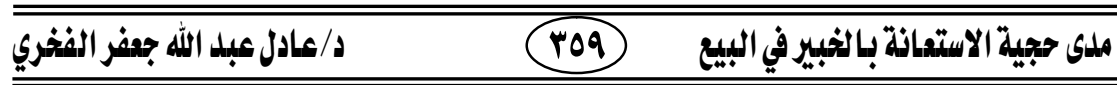

ـ حزم: علي بن أحمد بن سعيد المتوفى سنة 07؛هـ - الملبي - ط المنبرية ط .0. آهـ

ـ حطاب: محمد بن محمد عبد الرحمن المتوفى سنة ب90هـ - هواهب البليل

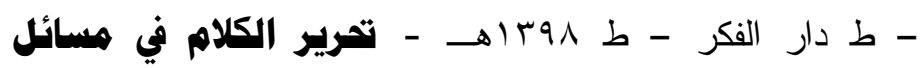

\section{الالترام.}

- حليمي: لؤي عبد الحميد الحليمي - الأحكام الشرعية للإضرابات في المهن الإنسانية في الفقه الإسلاهي - بحث في مكتبة كلية الثريعة

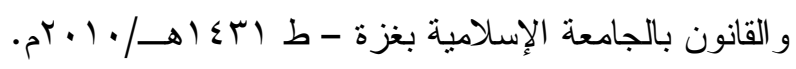

ـ حنبلي: ابو الفرج عبد الرحمن بن رجب الحنبلي المتوفى سنة وVهـــ - جاهـع العلوم والحكم - ط مكتبة دار التزاث.

- حيدر: علي حيدر - درر المكام شرح - مجلة الأحكام - ط دار الكتب العلمية . - ط

ـ خرشي: محمد بن عبد الله المالكي الخرشي - المنوفى سنة 1.11اهـ -

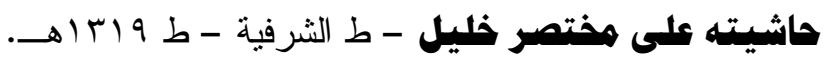

- خطيب: محمد بن أحمد الثربيني الخطيب - المتوفى سنة 9VVه هذبي

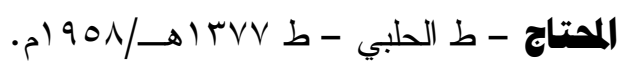

- خفيف: علي الخفيف - أحكام المعاملات الشرعية - ط دار الفكر .

- خلف اله: محمد أحمد خلف اله - هفاهيم قرآنية - الشورى وولاية الأهر - منائ

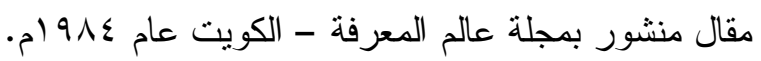

ـ داود: سليمان بن الأشعث بن إسحاق المتوفى سنة r.rهـ - سننه - ط

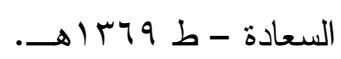




\begin{tabular}{lll}
\hline \hline مجلـة الدرايـــة \\
\hline \hline
\end{tabular}

- دسوقي: محمد بن عرفه المتوفى سنة .بrاهـ - حاشيته على الشرح

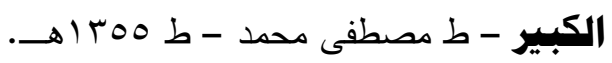

ـ رازي: محمد بن عمرو بن الحسن بن الحسين المتوفى سنة 7 .7هـ - تفسير

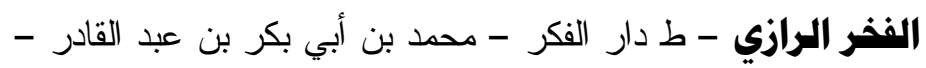

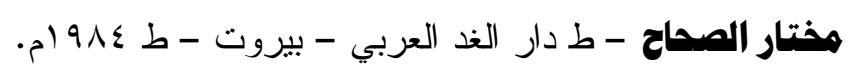

- رشد: محمد بن أحمد بن رشد القرطبي - المتوفى سنة . بهــ - الاقدهات والممدات - ط دار السعادة.

- رشدي: محمد السعيد رشدي - أحكام عقد البيع - ط بو ام.

ـ رملي: محمد بن أبي العباس المعروف بالثنافعي الصغير المتوفى سنة ؟ . . اهـ

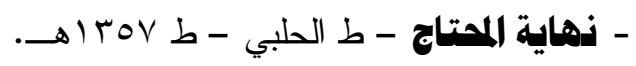

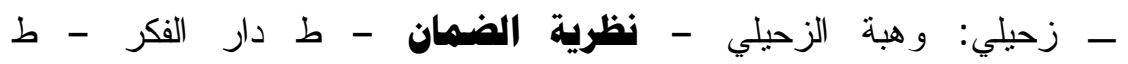

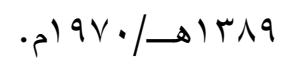

زرقاء: مصطفى أحمد الزرقاء - المدخل الفقهي العام - ط ألف ياء الأديب -

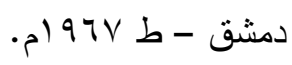

ـ الزرقاني: محمد بن عبد الباقي بن يوسف المتوفى سنة r الهـ - حاشيته

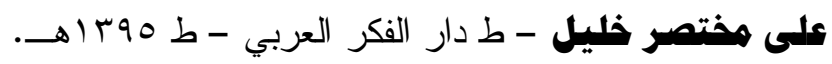

- زمخشري: جاد الله محمود بن عمر بن محمد الزمخشري المتوفى سنة مبههـ

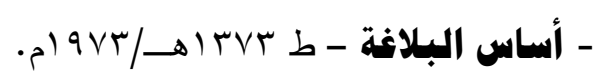

- زيلعي: جمال الدين عبد الله بن يوسف المتوفى سنة r بVهـ - تبيين الحقائق

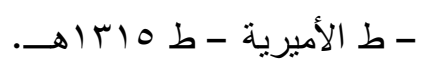

- سماوة: محمود بن إسرائيل - بن عبد العزيز المتوفى سنة بrیهـ - جاهـع

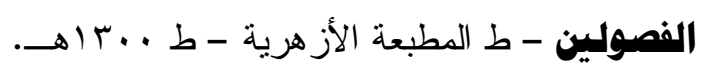




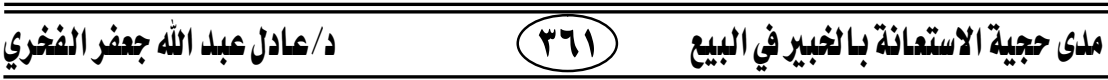

- سباعي: مصطفى السباعي - السيرة النبوية دروس وعبر - ط دار الور اق .

- سرخسي: محمد بن محمد رضي الدين المنوفى سنة الVهـ - المبسوط - ط دار السعادة.

- سعد: محد شتا أبو سعد - الشرط كوصف للتراضي في الشريعة الإسلاهية

$$
\text { . - ط - }
$$

ـ سعدي: تيسير الكريم الرحمن في تفسير كلام المنان - ط دار السلام.

ـ سمرقندي: علاء الدين السمرقندي - المتوفى سنة 9بهــ - تهفة الفقهاء -

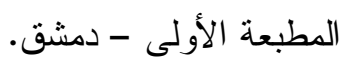

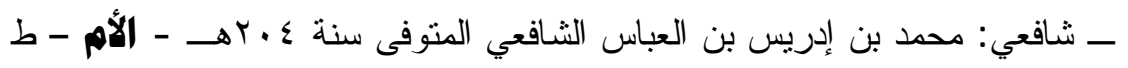

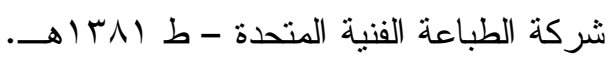

- شحاته: شفيق شحاته - النظرية العاهة في الالتراهات في الفقه الإسلاهي ط

ـ شرقاوي: عبد الله بن حجازي بن إبر اهيم الثرقاوي المنوفى سنة VYYهــ -

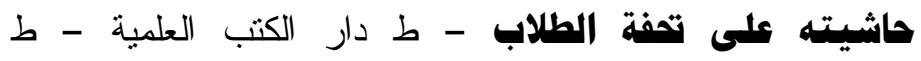

$$
.0199 \mathrm{~V} / \rightarrow 1 \text { (1) }
$$

- شيية: عبد الله بن محمد بن شيبة المنوفى سنة هبrهـ - هصنفة المعروف أهن

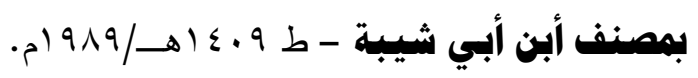

ـ شيخ: هشام بن عبد الملك بن عبد الله بن محمد بن آل الثيخ - أثر التقنية

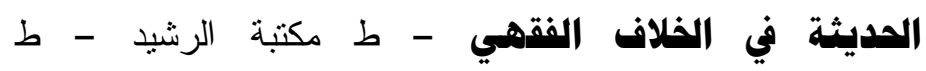

$$
\cdot 5 r \cdot v / \rightarrow \mid \leq r \wedge
$$

ـ شيرازي: إيراهيم بن علي بن يوسف الثيرازي - المتوفى سنة

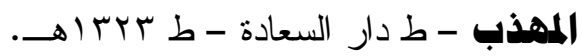




\begin{tabular}{|c|c|c|}
\hline العدد الخامس عشر 10+rم & MIP & مجلـة الدرايــــة \\
\hline
\end{tabular}

ـ صاوي: أحمد بن محمد الصاوي المالكي المتوفى سنة اء؟ارهـ - بلغة

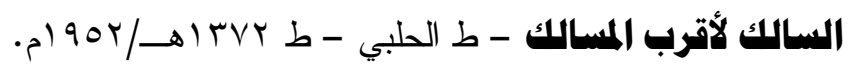

ـ طبر اني: أبو القاسم سليمان بن أحمد الطبراني المنوفى سنة . بسهـ - المعجم

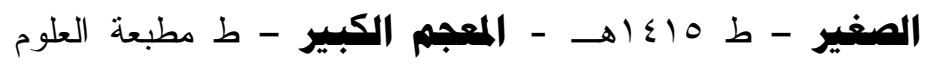

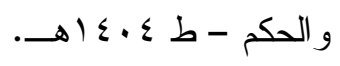

- طر ابلسي: أبو الحسن بن علي بن خليل المتوفى سنة ؟ــهـ - همعين الهكام

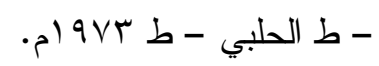

- طنطاوي: محمد سيد طنطاوي - التفسير الوسيط للقرآن الكريم - ط دار السعادة.

- طايع: حمدي إسماعيل طايع - الالترام بالصفظ والعناية في عقود المعاوضات

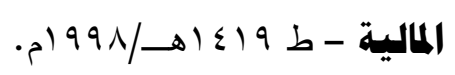

- عابدين: محمد بن عمر بن عبد العزيز المتوفى سنة ب0 أهـ - حاشيته رد المختار - ط هب أهـ - ط المطبعة الكبرى.

- عاملي: محمد عوده بن محمد بن حيدر الحسيني المتوفى سنة بrYMاهـ -

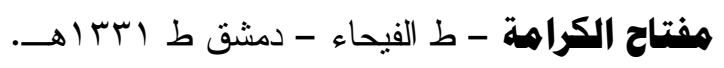

- عبد السلام: عز الدين محمد بن عبد العزيز السلمي المتوفى سنة . ب7هــ قواعد الأحكام في هصالح الأنام - ط دار إحياء الكتب.

- عبده: محمد عبده بن حسن خير الله المنوفى سنة بrسا(هـ - تفسير المنار -

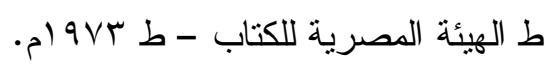

- عسقلاني: أحمد بن محمد بن حجر العسقاني - المنوفى سنة 10rهـ - فتح الباري بشرح صحيح البخاري - ط دار الريان. 


\section{ملى حجية الاستمانة بالغبير في البييع}

ـ عليش: محمد بن أحمد بن عليش المتوفى سنة وج9 اهــ - فتح العلي المالك في الفتوى على هذهب الإهام هالك - ط الحلبي - طن بندي

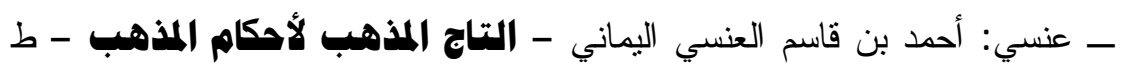

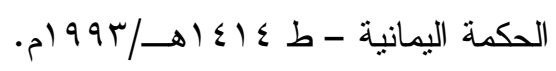

- غده: عبد الستار أبو غده - الخيارات وأثرها في التصرفات.

ـ غزالي: محمد بن محمد بن محمد الغزالي الطوسي المنوفى سنة 0.0هـ إحياء علوم الدين.

- فارس: أحمد بن فارس بن زكريا المتوفى سنة 90سهـ - هعبم هقاييس

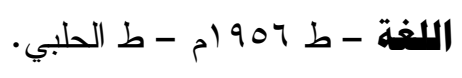

- فتح: أحمد أبو الفتح - المعاملات في الشريعة الإسلاميية - ط دار النهضة

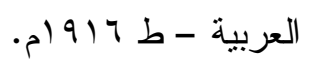

- فرج: نوفيق حسن فرج - عقد البيع - ط مؤسسة الثقافة الجامعية - ط . 910

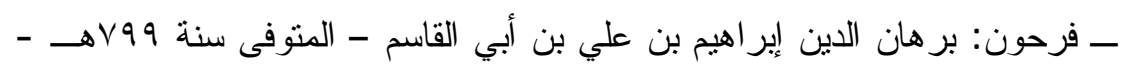

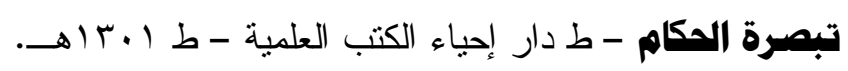

- فيومي: أحمد بن محمد بن علي الفيومي - المتوفى سنة •VVA - المبباح

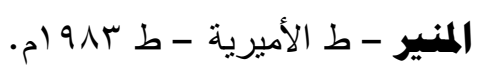

ـ قدامة: عبد الله بن أحمد بن محمد بن قدامة المتوفى سنة • لVTهـ - المغني -

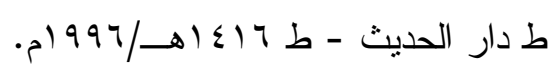

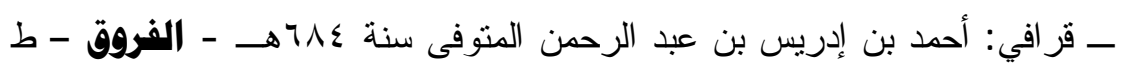

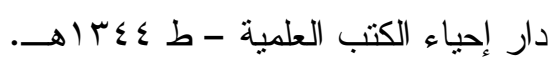




\begin{tabular}{|c|c|c|}
\hline العدد الخامس عشر 10بم & rys & مجلــة اللدرايســـة \\
\hline
\end{tabular}

ـ قرطبي: محمد بن أحمد بن أبي بكر فرج الأنصاري - المتوفى سنة الوTهـ -

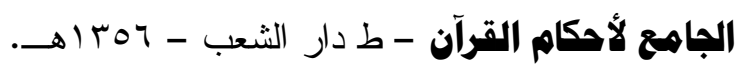

- قليوبي: أحمد بن أحمد القليوبي المنوفى سنة 99 × اهـ - حاشية قليوبي وعميرة على شرح المنهاج - ط دار إحياء الكتب العربية.

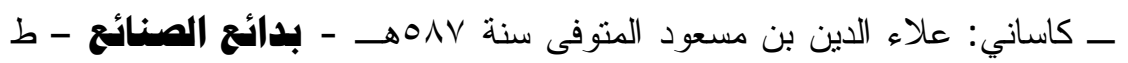

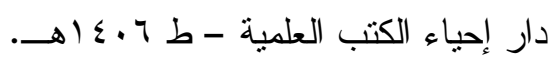

ـ ماجه: محمد بن يزيد بن عبد الله المنوفى سنة rVY - مالك: ماللك بن أنس بن ماللك المتوفى سنة لو اهـ - هوطأ الإهام هالك - ط

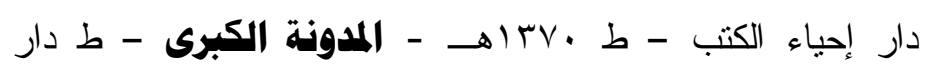

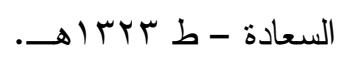

- مأمون: عبد الرشيد مأمون - البيع والقايضة. - مبروك: ممدوح - محمد علي مبروك - أحكام الملم بالمبيع وتطبيقاته في ضوء وسائل التكنولوجيا المعاصرة - رسالة دكتور اه مقدمة لكلية

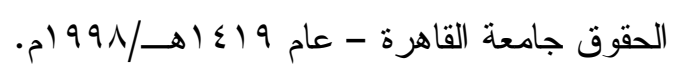

- مجمع: مجمع اللغة العربية - المعبم الوجيز - ط الأميرية - ط طاءية

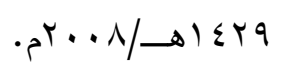

ـ مجلة: مجلة الفقه الإسلامي التابع لمنظمة المؤتمر الإسلامي بجدة السعودية -

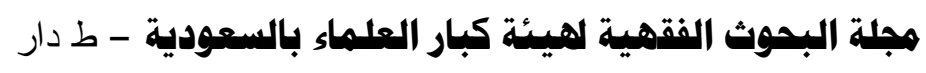

$$
\text { عالم الكتب - الرياض - ط } 990 \text { (م. }
$$

- مرتضى: أحمد بن يحيى المرتضى الحسيني المتوفى سنة .ـدهـ - البحر الزخار - ط مؤسسة الرسالة.

- مرسي: محمد كامل مرسي - البيع والمقايضة. 


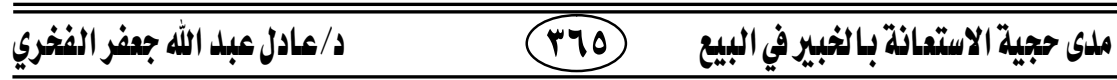

- مرغيناني: أبو الحسن علي بن أبي بكر الرشداني المنوفى سنة به09هـ -

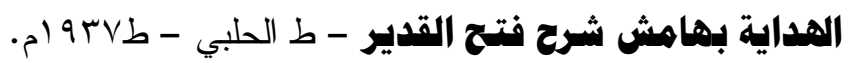

- مسلم: أبو الحسين بن الحجاج بن مسلم القتيري المتوفى سنة ابrهـ صميح هسلم - ط الحلبي - ط • 197 ام.

ـ مطيعي: محمد نجيب المطيعي - تكملة المجموع - ط مكتبة الإرشاد السعودية. - معجم: هعبم ألفاظ القرآن محمد علي النجار - ط .9 أهـ.

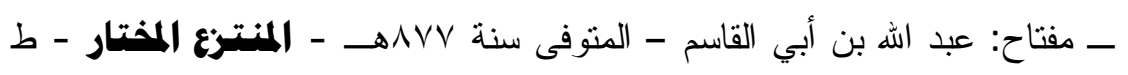

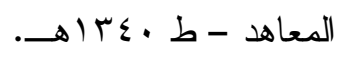

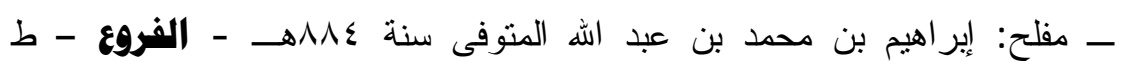

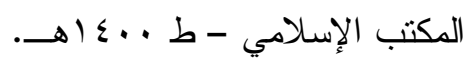

ـ منظور: جمال الدين محمد بن مكرم المصري المتوفى سنة IIاVهـ - لسان

$$
\text { العرب - ط صادر - بيروت - ط } 907 \text { ام. }
$$

ـ مو اق: محمد بن يوسف بن أبي القاسم المتوفى سنة ^و\هـ - التاج والإكليل

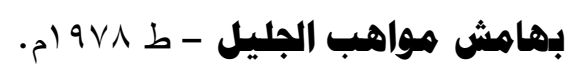

- موصلي: أبو الفضل عبد الله بن محمود بن مودود المنوفى سنة بریهـ - -

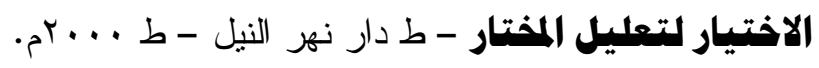

ـ نجار : عبد الله مبروك النجار - هبادئ عقد البيع - ط دار النهضة العربية -

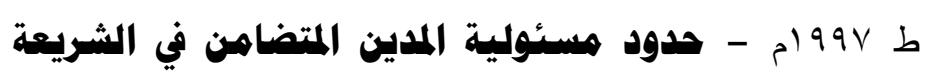
والقانون - رسالة ماجستير بكلية الثريعة و القانون - جامعة

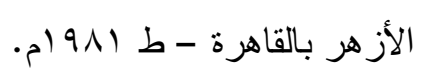

محمد الطيب النجار، عبد المقصود نصار - السيرة النبوية - ط قطاع المعاهد

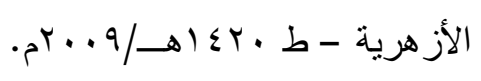




\begin{tabular}{|c|c|c|}
\hline العدد الخامس عشر 10 10م & ry9 & مجلــة اللدرايــــة \\
\hline
\end{tabular}

نجيم: زيد العابدين بن إبر اهيم المصري المتوفى سنة • وهـــ - البحر الرائق -

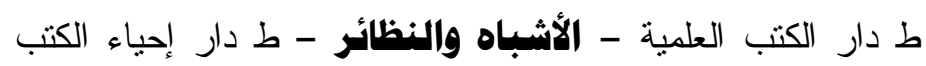

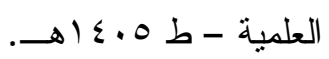

- نسائي: الحسين أحمد بن شعيب بن بحر المتوفى سنة r.باهـ - سننه ط دار إحياء الكتب.

ـ نفر اوي: أحمد بن غنيم بن سالم بن مهنا النفراوي - المتوفى سنة هب الهـ -

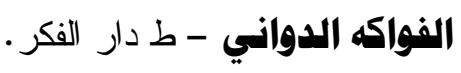

- نووي: يحيى بن شرف الدين بن مرة النووي - المتوفى سنة

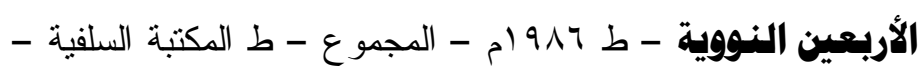

\section{روضة الطالبين.}

ـ هثام: محمد عبد الملك بن هشام - هنتصر سيرة ابن هشام - ط وزارة الأوقاف - المبل الأعلى للشئون الإسلاهيية - مركز السيرة

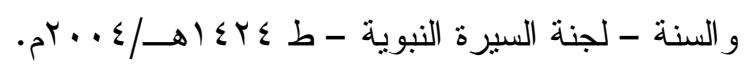

- همام: كمال الدين محمد بن عبد الواحد بن الهمام - المتوفى سنة اب1هــ -

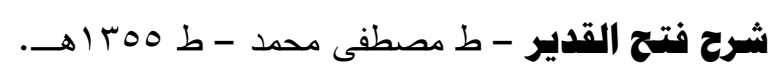

- هند: علماء الهند برئاسة العالم نظار الهندي - الفتاوى الهندية -

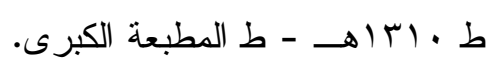

- وجيز : الوجيز في الميراث على المذاهب الأربعة - ط قطاع المعاهد الأزهرية - ط - 